\title{
Las cofradías en Cantabria: elementos para la comprensión de una estructura socio-religiosa significativa en los siglos XVI-XVIII
}

\author{
JosuÉ FONSECA* \\ IES Garcilaso de la Vega \\ The brotherhoods in Cantabria: elements for the understanding \\ of a meaningful social and religious structure \\ in the $16^{\text {th }}-18^{\text {th }}$ Centuries
}

\begin{abstract}
RESUMEN
Las cofradías y hermandades sodalicias tuvieron una cierta importancia, tanto en las estructuras de sociabilidad como en la configuración de los arquetipos religiosos

y devocionales colectivos del Antiguo

Régimen. El caso de Cantabria nos permite demostrar la relevancia

cuantitativa de dichas instituciones, así como su gran longevidad y capacidad de adaptación a los diferentes cambios socio-

políticos y culturales. De la misma manera, parece clara su adscripción a dos modelos bien diferenciados: uno de origen

y tipología claramente «popular» y otro promovido y controlado por las élites religiosas. Su estudio en este territorio de la antigua Castilla contradice tanto la teoría que las considera "reductos" de la antigua cultura tradicional, como aquella que ve en ellas el elemento decisivo en el triunfo del proceso de confesionalización.
\end{abstract}

PALABRAS CLAVE: cofradías / estructuras socio-religiosa / Cantabria / siglos XVI y XVIII

\begin{abstract}
Brotherhoods played a role of certain importance in the configuration of the archetypes of the practice and devotional features of the piety of the period. The case of Cantabria allows us to demonstrate the quantitative meaninfulness of these institutions, together with their long life and capacity to adapt themselves to different social, political and cultural changes. In the same way it seems clear their adscription to two different pattern : one of «popular» origin and typology and the other promoted and controlled by religious elites. In the context of this territory of Old Castile, they cannot be seen neither as strongholds of a popular culture (mainly expressed in foodrituals, and other community reinforcement signs), nor, in the other side, as the magnificent instrument of the process of confessionalization.
\end{abstract}

KEYWORDS:

Brotherhoods / religious structures /

Cantabria / 16th \& 18th Centuries

* IES Garcilaso de la Vega. San Roque G-20. Posadillo. 39313 - Polanco (Cantabria). e-mail: josuefons@gmail.com 
En los últimos años, el estudio de las cofradías religiosas y otros tipos diversos de hermandades sodalicias, ha pasado a ocupar un papel relevante dentro de la literatura científica dedicada al análisis del hecho religioso y social. Desde la antropología, la sociología y la psicología social, o la propia historia, son muchas las aproximaciones realizadas con ópticas muy variadas y enfoques (cada vez más) de carácter interdisciplinar.

El período comprendido entre los siglos XVI y XIX acapara un porcentaje considerable de dicha bibliografía. La rica documentación conservada, por un lado, y la importancia del fenómeno como elemento esencial en el estudio de la gestación del «catolicismo popular postridentino» han constituido sin duda dos causas relevantes de tal abundancia. Si ello es válido genéricamente para toda la cristiandad latina desde finales del siglo XVI, aún lo es más para el caso español, en el cual las cofradías revistieron una importancia extraordinaria, bien reflejada por otra parte en numerosos trabajos de investigación'.

${ }^{1}$ La bibliografía actual sobre las cofradías españolas es muy abundante, aunque desigual según las regiones. Andalucía ha sido el territorio más privilegiado, como resulta lógico por otra parte: LÓPEZ MUÑOZ, Miguel Luis, Las cofradías de la parroquia Santa María Magdalena de Granada, ss. XVII-XVIII, Granada, 1992; del mismo autor, Contrarreforma y cofradías de Granada: aproximación a la historia, Granada, 1992; y La labor benéfico-social de las cofradías en la Granada moderna, Granada, 1994; MORENO NAVARRO, Isidoro, Las cofradías de Sevilla, Sevilla, 1983; GARRIDO AGUILERA, Juan Carlos, Religiosidad popular en Jaén durante los siglos XV y XVI: las cofradías, Jaén, 1987; GIL ALBARRACÍN, Antonio y GONZÁLEZ DE LEÓN, Fernando, Cofradías y Hermandades en la Almería moderna: historia y documentos, Sevilla, 1997; LERÍA, Antonio; Cofradías de Carmona: de los orígenes a la ilustración, Sevilla, 1998; RODRÍGUEZ-MOÑINO SORIANO, Rafael, CRUZ CABRERA, José Policarpo y CRUZ MARTÍNEZ, Damián, Historia documental de las cofradías y hermandades de penitencia en la ciudad de Baeza, Baeza, 1997; SÁNCHEZ LÓPEZ, Juan Antonio, Muerte y cofradías de pasión en la Málaga del siglo XVIII, Málaga, 1990; PÉREZ LÓPEZ, Santiago, Las cofradías de Semana Santa en Guadix: la Hermandad del Santo Entierro, desde sus orígenes a nuestros días, Guadix, 1999; LINARES PÉREZ, Manuel Ángel, Compendio histórico-epigráfico de las cofradías de Málaga, Granada, 2000; AGUAYO EGIDO, Francisco, Las cofradías de la villa de Guadalcazar durante la modernidad, Córdoba, 2003; CXIX reglas de hermandades y cofradías andaluzas: siglos XIV, XV y XVI, Huelva, 2003. Para Castilla: LINAGE CONDE, Antonio, Las Cofradías de Sepúlveda, Madrid, 1986; LOSADA AZORÍN, Alfredo Antonio, Historia de la Semana Santa de Hellín: cofradías y hermandades, Hellín, 1993; MARTíNEZ GONZÁLEZ, Rafael Ángel, Las Cofradías penitenciales de Palencia, Palencia, 1980; SOBRINO CHOMÓN, Tomás, Documentos de antiguos cabildos, cofradias y hermandades abulenses, Avila, 1988; RAMíREZ RODRí-

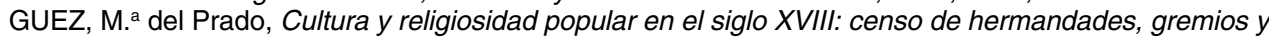
cofradias del conde de Aranda en la provincia de Ciudad Real, Ciudad Real, 1986; SABE ANDREU, Ana $\mathrm{M}^{\mathrm{a}}$, Las cofradías de Ávila en la Edad Moderna, Ávila, 2000; RECUENCO PÉREZ, Julián, Ilustración y Cofradías, la Semana Santa de Cuenca en la segunda mitad del siglo XIX, Cuenca, 2000; ALONSO DE PORRES FERNÁNDEZ, César, Cofradías y hospitales medievales burgaleses: santa Catalina y San Julián, Burgos, 2003; CALLAHAN, William James, "Corporate Charity in Spain, The Hermandad del Refugio of Madrid, 1618-1814», Histoire Sociale/Social History, 9, 17 (1976), pp. 159-186; ROMERO SAMPER, Milagrosa, Las cofradías en el Madrid del siglo XVIII, Madrid, 2003; ORDUÑA REBOLLO, Enrique y MILLARUELO APARICIO, José, Cofradías y sociedad urbana: la llustre Cofradía Penitencial de Nuestra Señora de las Angustias de Valladolid, Madrid, 2003. Para Extremadura Cfr.: CROCHE DE ACUÑA, Francisco, Gremios y cofradías de la villa de Zafra, ss. XVII-XVIII, Zafra, 1996; MIRA CABALLOS, Esteban, Hermandades y cofradías en Badajoz y su partido a finales de la Edad Moderna, Mérida, 2002; y HONTANILLA CENDRERO, Julián, Cofradías de las villas de la Dehesa de los Guadalupes: Castilblanco, Valdecaballeros y Alía (siglos XVII-XVIII), Madrid, 2004. En cuanto a Navarra: ARRAIZA FRAUCA, Jesús, Cofradías de Santiago en Navarra, Pamplona, 1998. En Murcia: MUNUERA RICO, Domingo, Cofradías y hermandades pasionarias en Lorca, Murcia, 1981. Para el caso de la propia Cantabria, Cfr. MANTE- 
Las antiguas «montañas Bajas» del obispado de Burgos que constituían la gran mayoría de los territorios encuadrados en la actual Comunidad Autónoma de Cantabria, representan un caso especialmente interesante por motivos que confluyen. En primer lugar, se trata de una zona hidalga y de vieja cristianización, pero un tanto marginal dentro de la Corona de Castilla. Por otro lado, pertenece al arco (no solo geográfico, sino también cultural) atlántico, con unas características propias y bien definidas, en el que el fenómeno aún está muy insuficientemente estudiado.

En realidad el interés científico actual en el estudio de estas asociaciones va mucho más allá de su propia realidad concreta: sus estatutos, sus formas de culto, su historia particular. Más bien debemos buscar en ellas un sustrato de creencias, representaciones y prácticas, que nos proporcionan el acceso más seguro con el que podemos contar al mundo complejo de las sensibilidades colectivas subalternas y sus relación con las directrices de élites en el marco del gran proceso de la confesionalización.

Así pues, la aparente simplicidad de su fundación, estructuras o funcionamiento no deben hacernos caer en interpretaciones erróneas o apresuradas en exceso: la hermenéutica de su realidad profunda, de su vida interior real, presenta una complejidad que no se puede soslayar con facilidad. Por otro lado y en dicha práctica hermenéutica, nos encontramos rápidamente con un problema de doble significatividad, clave a nuestro entender del enigma de lo que tradicional y discutidamente ha venido denominándose religiosidad popular. Así, de un mismo significante, hecho de estatutos, costumbres y prácticas concretas, podrían fácilmente extraerse dos significados contrapuestos: el de las jerarquías católicas, que veían con buenos ojos lo que consideraban un instrumento de piedad para los laicos al estilo tridentino, y el de los componentes de la hermandad que tal vez expresaban primordialmente rituales arcaicos de comensalismo y solidaridad comunal a través de la misma. A éstas y algunas otras preguntas intentaremos, modestamente, contestar en este artículo.

Una aproximación inicial al sujeto de nuestro estudio, nos lleva a una primera constatación que se impone con fuerza: estas instituciones eran muy numerosas en el período histórico que estamos estudiando. Según cálculos, estimados a la mínima $^{2}$, encontraríamos que hubo 105 cofradías fundadas, o que existían al menos en algún período del siglo XVII, en tanto que la centuria siguiente nos proporcionaría 167 registros nuevos, diferentes de los anteriores. A estas habría que sumar el corto pero significativo número de aquellas hermandades de las que conserva-

CÓN MOVELLÁN, Tomás Antonio, Contrarreforma y religiosidad popular en Cantabria. Las Cofradías religiosas, Santander, 1990.

2 Se han utilizado los registros existentes en el Archivo Diocesano de Santander (en adelante ADS), que proporcionan datos incontestables a través de su Catálogo General (ed. de 1983), el cual ha venido recibiendo nuevos añadidos inéditos en los últimos años, aunque obviamente hubo más hermandades de las que nos han legado sus registros escritos. 
mos documentación fechada en el quinientos: Vera Cruz del lugar de Isla (1515); Vera Cruz en Susilla (1538); Vera Cruz en Zurita (1569); Rosario en Argoños (1579); Vera Cruz en Bárcena de Cudón (1580) y Vera Cruz de Argoños (1597). De este modo, si tenemos en cuenta que son 624 los lugares sobre los que hemos hecho este muestreo, nos encontraremos con que al menos un $44,55 \%$ de localidades del actual territorio de Cantabria contaron con asociaciones de este tipo en el espacio cronológico elegido.

Otro dato que salta rápidamente a la vista es la enorme desproporción existente entre las distintas advocaciones. Así, encontramos un cierto número de hermandades cuyo índice de expansión geográfica las convierte en realidades devocionales de ámbito regional ciertamente merecedoras de ese nombre. Entre estas podríamos sin duda incluir a las tres más numerosas, es decir, El Rosario, La Vera Cruz y Las Ánimas, pero tan solo la primera de ellas cuenta con un nivel de extensión suficientemente identificado con la mayoría del actual territorio de Cantabria. La de Las Ánimas fue inexistente en la zona oriental; en tanto que La Vera Cruz tendió a concentrar en la mitad meridional el grueso de sus fundaciones. Otros casos, como es el de las congregaciones del Santísimo Sacramento, muestran una clara incidencia en Liébana, si bien llegan por el Sur hasta la Vega de Pas, y por el Este hasta el río Miera.

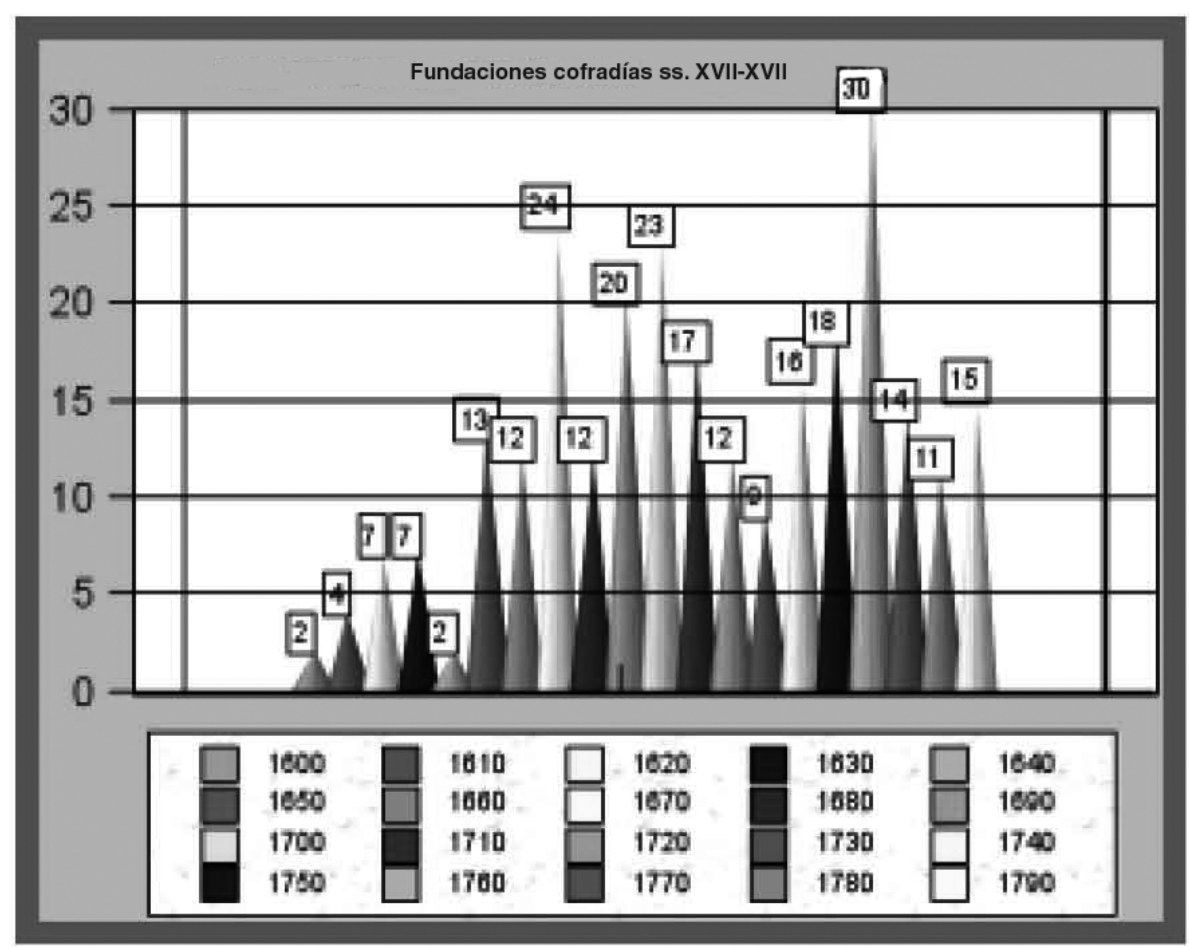

GRÁFICO 1. Fuente: Elaboración propia a partir de ADS, Catálogo, 1983. 
Las cofradías en Cantabria: elementos para la comprensión de una estructura...

El resto de las advocaciones son muy escasas, y algunas de ellas únicas, pues están adscritas a un santuario o ermita concretos. Enseguida veremos las diferencias en cuanto a reglas y objetivos que se establecieron entre unas y otras. Las cofradías experimentaron un claro empuje fundacional a partir de finales del siglo $\mathrm{XVI}^{3}$ acelerado al llegar la segunda mitad del XVII, y que se mantuvo sin grandes sobresaltos hasta finalizar el siglo siguiente ¿Significaría ésto que es en estos momentos en los que se produce el mayor número de fundaciones reales? Creemos que, salvando los errores que comportaría la pérdida de libros supuestamente extraviados, es esto lo más probable. Ello vendría a significar un crecimiento claro y sostenido del número de este tipo de asociaciones a partir de los años 50 del siglo XVII, con algunos momentos de actividad especialmente intensa en los períodos anteriormente señalados.

Demostrada la importancia numérica, debemos enfrentarnos a dos preguntas esenciales: ¿presentaban estas agrupaciones una semejanza institucional suficiente como para englobarlas a todas en un conjunto más o menos coherente? $\mathrm{Y}$, por otra parte: ¿eran razonablemente homologables entre sí sus contenidos devocionales? A primera vista las respuestas no parecen simples, especialmente en los casos en que la documentación escasea.

Hay que comenzar aceptando una consideración que rápidamente se impone con fuerza, y es la distinción entre los tipos de asociación que podríamos definir como «de carácter general» por contraposición a aquellas otras que tenían su origen en una piedad particular, básicamente ligada a un santuario o ermita, y casi siempre de carácter local o, como mucho, comarcal. De entre las primeras, las tres más numerosas (Rosario, Ánimas y Vera Cruz) son posiblemente también las más conocidas.

La devoción al Rosario jugó un importantísimo papel entre los contenidos devocionales propuestos por la confesionalización, de ahí el importante papel de las pías uniones destinadas a propagarla ${ }^{4}$. La Orden Dominicana, a través de su General, se reservaba el derecho de erección de cada nueva institución, que perma-

${ }^{3}$ Pese a la prudencia con la que hay que tomar la fuente con la que estamos estableciendo estas conclusiones preliminares no nos cabe duda de que la escasez de datos correspondientes al XVI no se debe prioritariamente a una falta de conservación de registros que hubieran podido existir y no se han conservado, sino a una falta clara de fundaciones.

${ }^{4}$ La historia de éstas no parece poder datarse con mucha anterioridad al inicio del último cuarto del siglo XV, cuando Alan de Rupe fundó las primeras agrupaciones con esta intención específica, de entre las que destacó especialmente la instituida en Colonia en 1474 por Jacob Sprenger. No fueron, indudablemente, las únicas asociaciones laicales de inspiración o dirección claramente dominicanas, pero sí (parecen ser) las primeras que surgieron con una orientación decididamente clara y estructurada sobre la práctica de esta devoción mariana. En todo caso, ya desde sus orígenes, las cofradías de El Rosario experimentaron un éxito notable, que las hizo extenderse por Europa con celeridad (su presencia está datada en Inglaterra, por ejemplo, ya en 1486 (Plumpton Correspondance, 50. Cit. por THURSTON, Herbert, "Confraternity of the Holy Rosary", The Catholic Encyclpedia, New York, 1913, vol. XIII). Ya en esa fecha se conserva el testimonio de un sacerdote londinense que escribe a su patrón en Yorkshire en los términos siguientes:") / send a paper of the rosary of our Lady of Coleyn, and I have registered your name with both my Ladies names, and the paper expresses, and ye be acopled as brother and sisters". 
necía bajo la supervisión directa de los visitadores de la misma. En la práctica existió desde los orígenes un control bastante estricto en cuanto a la consignación escrita de las entradas de nuevos miembros, lo que proporciona hoy una documentación relativamente importante.

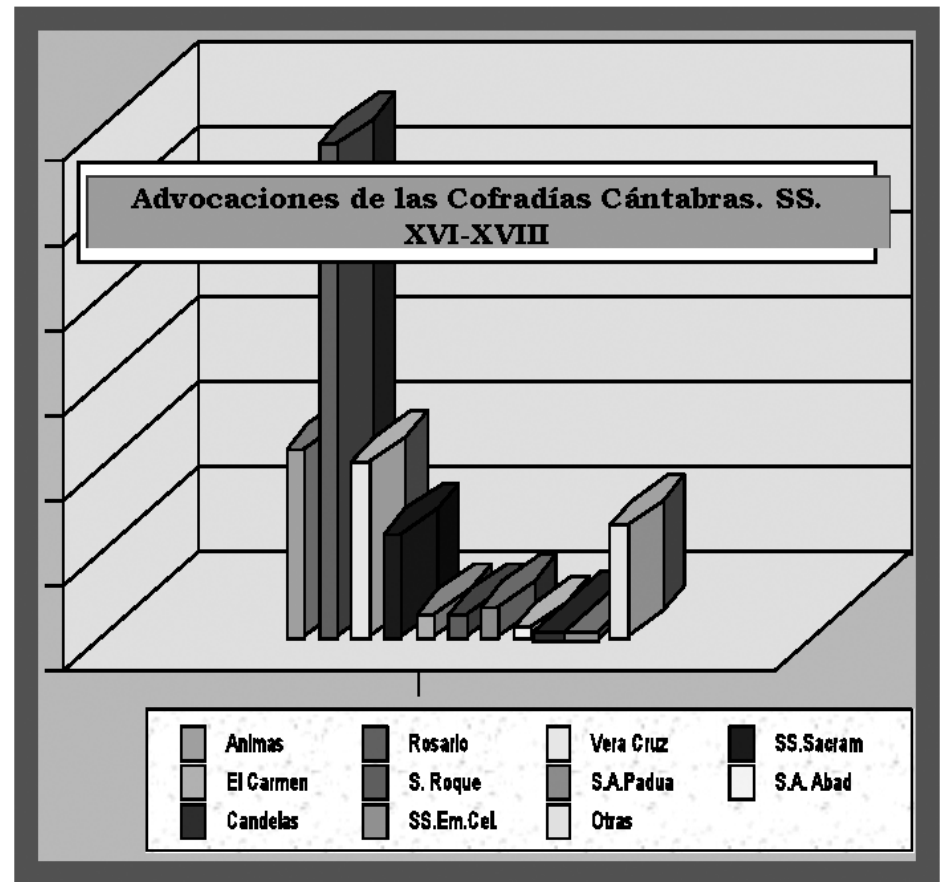

GRÁFICO 2. Fuente: Elaboración propia a partir de ADS, Catálogo, 1983.

En cuanto a los ritos de piedad, evidentemente el rezo del propio Rosario ocupó una posición axial, aunque no fue el único, y contribuyó notablemente a la normalización y homogeneización de esta práctica (alrededor, con toda probabilidad, del modelo consistente en la recitación de los 15 misterios), que los miembros debían observar con periodicidad al menos semanal. Por otro lado, la enorme cantidad de indulgencias que podían ser obtenidas, así como la participación en «todas las buenas obras realizadas en el mundo, por la Gracia de Dios, por los hermanos y hermanas de la Orden Dominicana», contribuyeron sin duda a la enorme extensión que experimentaron estas hermandades a lo largo y ancho de la cristiandad católica ${ }^{5}$. El primero de los aspectos era impresionante. En el cuadro siguiente podemos ver, a modo de ejemplo, las gracias espirituales que tenían a su alcance los miembros de una cualquiera de ellas, con la obra de piedad necesaria, la festividad y el Pontífice otorgante.

5 THURSTON, Herbert, "Confraternity..." 
Las cofradías en Cantabria: elementos para la comprensión de una estructura...

\section{CUADRO 1. Las indulgencias de la Cofradía del Rosario de Bárcena de Cicero (Cantabria año 1680)}

\begin{tabular}{|c|c|c|c|}
\hline Obras de piedad & Indulgencias & Festividad & Otorgante \\
\hline $\begin{array}{l}\text { Entrar en la Cofradía } \\
\text { Rezar quincuagena } \\
\text { Comulgar en la iglesia }\end{array}$ & Plenaria & $\begin{array}{l}\text { Día de ingreso } \\
\text { en la Cofradía }\end{array}$ & Pío V \\
\hline Rezar Rosario entero & $\begin{array}{l}\text { Plenaria; } 98 \text { años, } \\
32 \text { cuarentenas, } \\
150 \text { días }\end{array}$ & $\begin{array}{l}\text { Cualquier día, } \\
\text { o semana. } \\
\text { Sin especificar }\end{array}$ & $\begin{array}{l}\text { Paulo III, } \\
\text { «Otros Papas» }\end{array}$ \\
\hline Rezar una quincuagena & $\begin{array}{l}5 \text { y } 5 \text { cuarentenas; } \\
70.000 \text { años de } \\
\text { perdón }\end{array}$ & Sin especificar & $\begin{array}{l}\text { Sixto IV } \\
\text { Inocencio VIII }\end{array}$ \\
\hline $\begin{array}{l}\text { Rezar el Ave María, } \\
\text { diciendo, al cabo, } \\
\text { «Jesús» cada vez }\end{array}$ & $\begin{array}{l}5 \text { años, } \\
5 \text { cuarentenas, } \\
150 \text { días }\end{array}$ & Sin especificar & $\begin{array}{l}\text { Urbano IV, Juan XXII } \\
\text { Inocencio VIII, Pío V }\end{array}$ \\
\hline $\begin{array}{l}\text { Comulgar y rezar } \\
\text { quincuagena, visitar el } \\
\text { altar del } R^{\circ}\end{array}$ & $\begin{array}{l}\text { Indulgencia } \\
\text { plenaria }\end{array}$ & La Anunciación & Pío V \\
\hline $\begin{array}{l}\text { Comulgar y rezar } \\
\text { quincuágena }\end{array}$ & $\begin{array}{l}10 \text { años } \\
\text { y } 10 \text { cuarentenas }\end{array}$ & $\begin{array}{l}\text { La Resurrección } \\
\text { y la Anunciación }\end{array}$ & Pío V \\
\hline $\begin{array}{l}\text { Comulgar y rezar } \\
\text { quincuágena }\end{array}$ & $\begin{array}{l}7 \text { años } \\
\text { y } 7 \text { cuarentenas }\end{array}$ & $\begin{array}{l}\text { Anunciación, } \\
\text { Asunción y Ndad. } \\
\text { de } N^{a} S^{a}\end{array}$ & Sixto IV \\
\hline Rezar quincuágena & 100 días de perdón & $\begin{array}{l}\text { Cada fiesta de } \\
\mathrm{N}^{a} \mathrm{~S}^{a}\end{array}$ & «Legado Alexandro» \\
\hline $\begin{array}{l}\text { Rezar la Salve en la } \\
\text { Iglesia de El Rosario }\end{array}$ & 40 días & $\begin{array}{l}\text { Sábados, } \\
\text { Domingos o fiestas }\end{array}$ & «Legado Alexandro» \\
\hline Visitar el altar del $\mathrm{R}^{\circ}$ & Plenaria & $\begin{array}{l}\text { Cada fiesta } \\
\text { de } N^{a} S^{a}\end{array}$ & Pío V \\
\hline Ir a la procesión & Plenaria & $\begin{array}{l}\text { Primer Domingo } \\
\text { mes }\end{array}$ & Pío V \\
\hline $\begin{array}{l}\text { Ir a la procesión } \\
\text { los no cofrades }\end{array}$ & $\begin{array}{l}7 \text { años } \\
\text { y } 7 \text { cuarentenas }\end{array}$ & $\begin{array}{l}\text { Primer Domingo } \\
\text { mes }\end{array}$ & Pío V \\
\hline $\begin{array}{l}\text { Encargar misa del } \mathrm{R}^{\circ} \\
\text { Decir la misma misa } \\
\text { Oír la misma misa }\end{array}$ & $\begin{array}{l}\text { Lo mismo que } \\
\text { rezando todo el R. }\end{array}$ & Sin especificar & Paulo III \\
\hline $\begin{array}{l}\text { Traer consigo El Rosario, } \\
\text { «de suerte que otros le } \\
\text { puedan ver» }\end{array}$ & $\begin{array}{l}200 \text { años } \\
\text { y } 200 \text { cuarentenas } \\
\text { de perdón }\end{array}$ & $\begin{array}{l}\text { Cada día que así } \\
\text { lo hiciere }\end{array}$ & $\begin{array}{l}\text { Inocencio VIII } \\
\text { Alejandro VI }\end{array}$ \\
\hline $\begin{array}{l}\text { Asistir a los } 4 \text { aniversarios } \\
\text { en el C. de Sto. } D^{\circ} \text {, por } \\
\text { los c. difuntos }\end{array}$ & 1.800 años & $\begin{array}{l}\text { Cada vez que se } \\
\text { celebraren }\end{array}$ & Sixto IV \\
\hline
\end{tabular}

(Continúa) 
(Continuación)

\begin{tabular}{|c|c|c|c|}
\hline Obras de piedad & Indulgencias & Festividad & Otorgante \\
\hline Morir comulgado & Plenaria & momento del óbito & Pío V \\
\hline Morir (sólo siendo c.) & Plenaria & momento del óbito & Inocencio VIII \\
\hline $\begin{array}{l}\text { Visitar } 5 \text { altares y rezar } \\
\text { Pater Noster y Avemarías; } \\
\text { o } 25 \text { de ambos, si no hay } \\
\text { tantos, en los que hubiere }\end{array}$ & $\begin{array}{l}\text { Todas las } \\
\text { Indulgencias } \\
\text { ganadas por los } \\
\text { visitadores de las } \\
\text { iglesias de Roma } \\
\text { en ese día }\end{array}$ & Sin especificar & $\begin{array}{l}\text { León } \mathrm{X} \\
\text { Confirmado Pio V }\end{array}$ \\
\hline $\begin{array}{l}\text { Rezar } 25 \text { Pater Noster } \\
\text { y } 25 \text { Avemaría los presos } \\
\text { o impedidos, ante una } \\
\text { imagen de } \mathrm{N}^{\mathrm{a}} \mathrm{S}^{\mathrm{a}}\end{array}$ & $\begin{array}{l}\text { Todas las } \\
\text { indulgencias } \\
\text { ganadas por los } \\
\text { visitadores de las } \\
\text { iglesias de Roma } \\
\text { en ese día }\end{array}$ & Sin especificar & Pío V \\
\hline $\begin{array}{l}\text { Visitar los } 5 \text { altares } \\
\text { y rezar } 24 \text { Pater Noster } \\
\text { y Avemarías }\end{array}$ & Plenaria & $\begin{array}{l}\text { Cualquier día } \\
\text { del año }\end{array}$ & León X \\
\hline
\end{tabular}

Fuente: Elaboración propia, a partir de ADS, sig. 5677

Tal número de gracias debió influir notablemente en la expansión de este tipo de hermandades, que, por otro lado, se benefició claramente del impulso misionero de los frailes Predicadores, cuya labor fue en Cantabria mucho mayor y más eficaz que la de las otras órdenes religiosas en el siglo XVII dentro del ámbito rural. La distribución geográfica de los conventos, de inmejorables características estratégicas, permitió una penetración globalizada y regular a lo largo de la práctica totalidad del territorio montañés, lo que explica la homogeneidad de que gozó la implantación de estas instituciones ( $\mathrm{y}$ al contrario de lo que sucedió en el caso de otras con diferente advocación).

Las Cofradías de La Vera Cruz desempeñaron un papel de gran importancia en la región, tan solo superado en el aspecto cuantitativo por las de El Rosario, y en menor medida por las de Ánimas, a las que preceden, no obstante, cronológicamente ${ }^{6}$.

6 El culto a la «Vera Cruz» puede encontrarse definido ya en cierta manera en Nicea II, que le concede un rango especial entre todas las reliquias, y su veneración sufrió los avatares y controversias que, en general, han padecido todas las imágenes sacras. Trento definió con claridad los límites y características de este tipo de devociones en su vigesimoquinta sesión (aunque el tema había sido largamente debatido con anterioridad por Sto. Tomás, S. Alberto Magno, S. Buenaventura o Alejandro de Hales. Con posterioridad Bossuet abundaría aún más en el tema). Esa misma antigüedad podemos encontrarla en el interés por las reliquias del «madero Santo», datada cuando menos ya en 359, y, según Egeria, S. Cirilo de Jerusalén, su contemporáneo afirmaba como: «toda la tierra habitada está llena de reliquias del madero de Cristo» (Cfr. CABROL, Fernand «The True Cross», The Catholic... vol. IV). Sobre esta devoción William CHRISTIAN señala en Local Religion in Sixteenth Century Spain, Princeton, 1981, p. 184: «Each parish and brotherhood had a processional cross. These crosses and relics of the True Cross in 
Las cofradías en Cantabria: elementos para la comprensión de una estructura...

Es preciso recordar, aunque sea un dato tópico, que la cofradía de Sto. Toribio posteriormente denominada de la Santa Cruz, data del año $1181^{7}$.

Ya hemos visto como Cantabria no fue a la zaga, ni en número ni en cronología. De hecho, en la época Moderna, el caso de Isla (1515) se adelanta en algunos años a la más antigua cofradía castellana de la misma advocación, en tanto que Susilla (1538) está en plena coincidencia con el auge de las de aquella región. Además de otras prácticas comunes al resto de hermandades, la flagelación, especialmente característica de su piedad, sufrió una evolución imparable desde finales del siglo XVII y durante toda la centuria siguiente, en un proceso que hacía que los hermanos «penitentes» fuesen convirtiéndose paulatinamente en simples «alumbrantes», figurantes en el duro proceso penitencial que suponía la procesión de Jueves Santo (aunque mantuviesen el hábito de los disciplinantes en función de un «lucimiento» muy apreciado en la época). Lo cierto es que las disposiciones en los libros de cofradía señalan un proceso irreversible que parecía huir de la violencia física con distintos subterfugios y que éstas se veían en la imposibilidad de atajar. La prohibición estatal de dichas prácticas en 1777 no supuso más que la rúbrica en el acta de defunción de esta variante devocional colectiva ${ }^{8}$.

major cities, were used to conjure locusts and hail-bearing clouds, and in some places to dip in streams or ocean for rain. In late medieval theology, the cross was a sign of great power to turn back the devil, and hail and locusts were as much of 'the enemy' as Albigensians, Turks, and Moors".

7 Aunque sea preciso tener en cuenta que tal vez este ejemplo concreto no pueda ser totalmente asimilable al tipo que estamos estudiando, estando probablemente mucho más cerca de las sodalitas medievales, tal como se describe más adelante. En todo caso, algo parecido debió suceder en el resto de la Corona de Castilla, donde tenemos testimonios de la existencia de estas congregaciones en lugares como Toledo, Sevilla o Zamora ya durante el siglo XV, aunque no se trató probablemente de auténticas cofradías de flagelantes. Por el contrario, éstas sí aparecen documentadas a principios del XVI en lugares como Cáceres (1521), Cabra (1522), Villalpando (1524), Toledo (quizá a partir de alguna existente ya, antes de 1536); Sevilla (1538), Baeza (1540), Jaén (1541) y Jerez (1542). Su éxito, inmediato, se refleja con suficiente claridad en la enorme cantidad de cofrades que algunas llegaron a poseer. La Vera Cruz de Cáceres, concretamente, llegó a alcanzar la cifra de 850 miembros en el siglo XVI (GERBET, Marie Claude, «Les confrèries religieuses à Cáceres de 1467 à 1523», Mélanges de la casa de Velazquez, $n^{\circ} 7$ (1971), pp. 75-105).

8 Cfr. MANTECÓN MOVELLÁN, Tomás, Contrarreforma y ..., pp. 154-157. Los rituales penitenciales públicos habían tenido, no obstante, una importancia muy notable en el conjunto de la religiosidad popular (que no guarda paridad suficiente con nuestros conocimientos al respecto) a lo largo de toda la edad Media y Moderna. En relación con La Vera Cruz, sabemos que hubo ciertas reticencias en la aceptación de la flagelación, sin duda ninguna motivadas tanto por el juicio crítico expresado por la Iglesia, que veía en ellas un caldo de cultivo propiciatorio de conductas exageradas, como por un erasmismo más fuerte de lo que podría suponerse en ciertos estratos y en cuyo espíritu cuadraban mal este tipo de expresiones de fe. Lo cierto es que, a pesar de todo (y es interesante comparar la cronología expansiva de la práctica con los hitos del declive del «humanismo cristiano»), la costumbre fue extendiéndose, alentada por los beneficios espirituales concedidos por la propia jerarquía católica, así como por el decidido apoyo de la Orden franciscana, cuya influencia en la Península fue extraordinario. No deja de ser curiosa la propagación del espíritu de la «Vera Cruz» en multitud de hermandades particulares de flagelantes, que adoptaron otros nombres: Las Angustias, El Santo Nombre de Jesús o La Soledad, contaban en el Toledo de 1575 con membrecías que oscilaban entre los 600 y los 2.000 hermanos. La Cofradía de Santa Elena, salía con penitentes cargando pesadas cruces de madera durante la Semana Santa. Sabemos que en otros lugares como la modesta Jaén, existieron al finalizar el siglo 5 cofradías más de flagelantes, que partiendo una vez más de La Vera Cruz (fundada en 1541), habían ido extendiendo la costumbre del castigo por los pecados progresivamente (así, Las Angustias y las Cinco Llagas en 1551, La Soledad en 1556, El Santo Sepulcro en 1580, y Santa Elena entre 1588 y 1594). Algunas de ellas (Soledad y Santo 
En el caso de Cantabria, las hermandades ligadas a la devoción de la Santa Cruz fueron con toda probabilidad, y también aquí de la mano de la Orden franciscana, iniciadoras primordiales en la costumbre de la flagelación pública, continuada luego por agrupaciones cronológicamente posteriores como Las Ánimas, y que recibió también un cierto impulso de grupos devocionales ligados al medio dominicano de El Rosario y otros. No cabe duda de que el espectáculo de penitentes y alumbrantes recorriendo las callejas de muchos lugares fue común en la región durante largos años. La Semana Santa, El Corpus y sin duda otras ocasiones especiales (recordemos la peste de finales del XVI), fueron los tiempos privilegiados de estas manifestaciones, cuyo dramatismo no ocultaba de ordinario un cierto carácter festivo, igualmente impulsor de una consolidación grupal a la que una comida fraternal se encargaba muchas veces de poner punto final.

Las Cofradías de Ánimas representaban una de las tradiciones más antiguas en el espectro de la piedad asociativa ${ }^{9}$, y se especializaron paulatinamente en el socorro de las almas de los difuntos, actuando en una perspectiva doble: por un lado, como entidad «caritativa» (puesto que los beneficios de sus prácticas de piedad tenían la intención de alcanzar en un sentido amplio a todos los fieles cristianos) y, por otro, como sociedad «fraternal», que garantizaba importantes auxilios espirituales post mortem a cada cofrade, además de los vínculos de solidaridad y cierta ayuda mutua, comunes a todas las asociaciones de este tipo en el aspecto material o social ${ }^{10}$. Su extensión (es la segunda, tras El Rosario, de la que más re-

Sepulcro) habían comenzado su andadura con un número de cofrades superior al millar. Cfr. CHRISTIAN, William, Local Religion ..., p. 186.

9 Sus orígenes pueden ser rastreados hasta los tiempos de la Iglesia primitiva. El culto en las catacumbas presenta ya elementos importantes de esta práctica, tanto en lo devocional como en lo comunitario. En el 336 la hermandad de Constantinopla, ya presenta estos elementos de interés por los difuntos según señala BARONIO (Annales ad. An 336, Lucca, 1739). El interés fue mantenido en los siglos siguientes por el monacato emergente, particularmente de algunas ramas benedictinas que, como Cluny, inauguraron festividades como la de «Todos los Santos». Por otro lado, la sociedad entera parece concienciada de que los deberes de caridad se extiendan también a los difuntos como sucedía en algunos gremios (costumbre que se encuentra aún hoy, muy descontextualizada, pero viva aún, en rituales como el «Padrenuestro por los fallecidos» habitual en algunas monterías). Aunque no puedan ser llamadas estrictamente "Cofradias» en el sentido más reciente del término las hermandades de tipo Totembünde se extienden a lo largo de toda la Edad Media (tras un gran auge a partir del siglo VI y la época carolingia) como una serie de grupos de ayuda mutua en cuanto a lo sobrenatural, que llegaban a incluir a todas las clases sociales, y en las cuales se especificaban detalladamente los recursos espirituales a los que tenía derecho cada cofrade tras su deceso. La influencia de estas y otras asociaciones parece haber sido extraordinaria, aunque no estemos hoy en condiciones de evaluarla con exactitud. Prueba de la misma sería la gran cantidad, no solo de nobles y príncipes seculares que se contaron entre sus filas, sino los obispos y abades que habían llegado a formarse de una u otra forma en ellas. Los concilios y sínodos medievales la fomentaron decididamente, y no cabe duda de que llegaron a ser parte importante de la vida de cierto tipo de clero. La costumbre de realizar costosas fundaciones monacales por parte de las clases privilegiadas con el fin de garantizar sufragios colmados y permanentes por sus almas se extendió a partir de ejemplos señeros, como fue el de los reyes ingleses o los carolingios, y llegó hasta los rincones más recónditos, incluidos los de la Cantabria rural (una muestra especialmente clara sería Sta. María de Yermo, la joya del románico montañés).

11 Las Confraternitates, más parecidas en su forma a las de la época que estamos tratando y cuya atención se centró fundamentalmente en el socorro a Las Ánimas del Purgatorio existieron igualmente desde tiempos muy antiguos: parece ser que una antigua inscripción citada por BARONIO (Annal., XVI, 
gistros se conservan), indica la influencia que estas prácticas llegaron a tener, de una manera u otra, en el conjunto global de la sociedad montañesa.

El resto de las cofradías se refería a advocaciones muy variadas, como ya hemos visto y, en teoría, independientes. Sin duda ninguna, dentro de este segundo grupo llaman la atención de manera especial las fundadas con carácter mariano, las cuales, al margen naturalmente de la enormemente extendida de El Rosario, presentan nada menos que dieciseis advocaciones distintas, tan sólo repetidas en dos ocasiones (Nuestra Señora de Las Candelas en Arnuero y Meruelo ${ }^{11}$ y Nuestra Señora del Carmen en Argüeso, Castillo-Pedroso, Cosío, Iruz y Torices ${ }^{12}$ ).

¿Cual fue el objetivo, o característica principal de las mismas? La teoría se presenta con claridad y contundencia en la introducción a la Regla Nueva de Santa María de Hormiguera que, en un lenguaje cargado de elementos expresivos propios de una religiosidad, entre popular y elitista, de sumo interés ${ }^{13}$, resume básicamente los

272, Lucca, 1774), señala cómo en la iglesia de los Santos Cosme y Damián de Roma un grupo indeterminado de obispos y sacerdotes formaban una agrupación de sodales, cuyo compromiso les obligaba a cantar, inmediatamente tras el óbito de uno de ellos, 40 misas por el reposo de su alma. A principios del siglo XI, Orc (amigo de Knut el Grande) erigió en Abbotesbury una cofradía en cuyos estatutos se estipulaba la entrega de un penique por parte de cada cofrade a la muerte de uno de ellos por su descanso (cfr. DUGDALE, Monasticon Anglicanum, London, 1821, t. III, p. 55). En las centurias siguientes contamos con testimonios parecidos en Sens (1220), Glocknitz (1355) y Toulouse (1413). Desde la etapa primitiva, en la que las beneficiarias de los auxilios espirituales post mortem eran las almas de cofrades o benefactores, se pasó en los siglos siguientes a la idea universal de sufragio por las «pobres almas» en general. Es probable que fuera Italia la cuna de este tipo de nuevas instituciones. Desde la fundación de la Compagnia de la Pietà (1448) o los «Penitentes Blancos» (1488) en Roma, multitud de iniciativas de este tipo verán la luz, como Mortis et Orationis (1538) o Sta. Maria del Suffraggio (1592), por toda la Cristiandad, y las fundaciones se multiplicarán de forma extraordinaria hasta finales del siglo XIX (cfr. HILGERS, Joseph, «Purgatorial Societies», en The Catholic..., vol. XII). Las Cofradías de Animas estaban perfectamente consolidadas en España y en la propia Cantabria en el siglo XVI. Algunas de ellas alcanzaron una extraordinaria longevidad (existen casos que perduran hasta el siglo XX).

11 ADS, sigs. 6263 y 3501 respectivamente.

12 ADS, sigs. 3818, 4588, 1265, 364 y 1997 respectivamente.

13 ADS, sig. 4378, fol. 1r-4r: «In Dei Nomine. Amén. Porque la vida de este mundo es brebe a las criaturas humanas, porque es dicho por Job quam brebes sun dies hominum, por tanto continuamente deven estar los hombres humanos fortalecidos de buenos pensamientos y obras, pues Nuestro Señor formó y hizo a los hombres para que moriessen manifestando en esto su grandeza y poderío porque ninguna otra cosa tan fácilmente estorva ni quita a los humanos de pecar como la frequente recordación de la muerte, como está dicho por Agustín: nihil sic revocat a peccato sicult frequens meditatio mortis. Pues en lo dicho no ay dudar razón será procuremos el favor de la Gloriosa, bendita y bienaventurada Virgen Sancta María, Madre de Dios y Señora Nuestra, porque así como el sol no communica sus rayos con la tierra sin que antes y primero los communique con el aire, ansí Nuestro Señor a ninguno haçe merçed sin que antes y primero intervenga el ruego de su gloriosa Madre, como es doctrina de los sanctos doctores de la Santa Madre Yglesia, mediante el fabor de la qual lebantan los hombres sus corazones al servicio de Dios Nuestro señor y la deboción y Regla de la sobre dicha virgen Santa María abogada Nuestra. Y porque Nuestro fin y paradero sea la Gloria del Paraysso. Como enseña la Santa Escriptura: ay del solo si cae y no hay quien le lebante!, ansí mesmo diçe que quando fueren dos o tres ajuntados en su nombre, en medio de ellos está Él. Por estas cosas y otras muchas que de la Escrituras Sanctas se pueden colegir de los dichos sanctos Padres a salvaçión y remedio de los bibientes y a suffragio de Las Ánimas defunctas, los hermanos confrades de la hermandad y confradía de Nuestra Señora Sancta María, agregada a la yglesia parroquial del [dicho?] lugar de Hormiguera y hermanos de la dicha confradía de Nuestra Señora Sancta María, hermita del dicho lugar de Hormiguera, acordamos de hacer una hordenaçión y regla por la qual Dios fuese más servido y cresciese en los humanos hombres más la deboción de la sobredicha Virgen Nuestra Señora, Patrona y abogada Nuestra y bibiésemos más a servicio de 
tres ítems: devoción mariana, servicio a Dios y cuidado de las ánimas. Tres fines muy generales, que parecen repetirse de una u otra manera en el resto de las $\mathrm{Re}$ glas conservadas ${ }^{14}$ y que empiezan a sugerirnos la idea de una gran uniformidad devocional en el trasfondo del conjunto, tan variado, de advocaciones. Una impresión, por otra parte, que no hace más que confirmarse si continuamos repasando los contenidos de las restantes hermandades, especialmente del gran grupo que escogía a un santo determinado como patrón.

\section{Santa Marina. Valdeprado: fines fundacionales.}
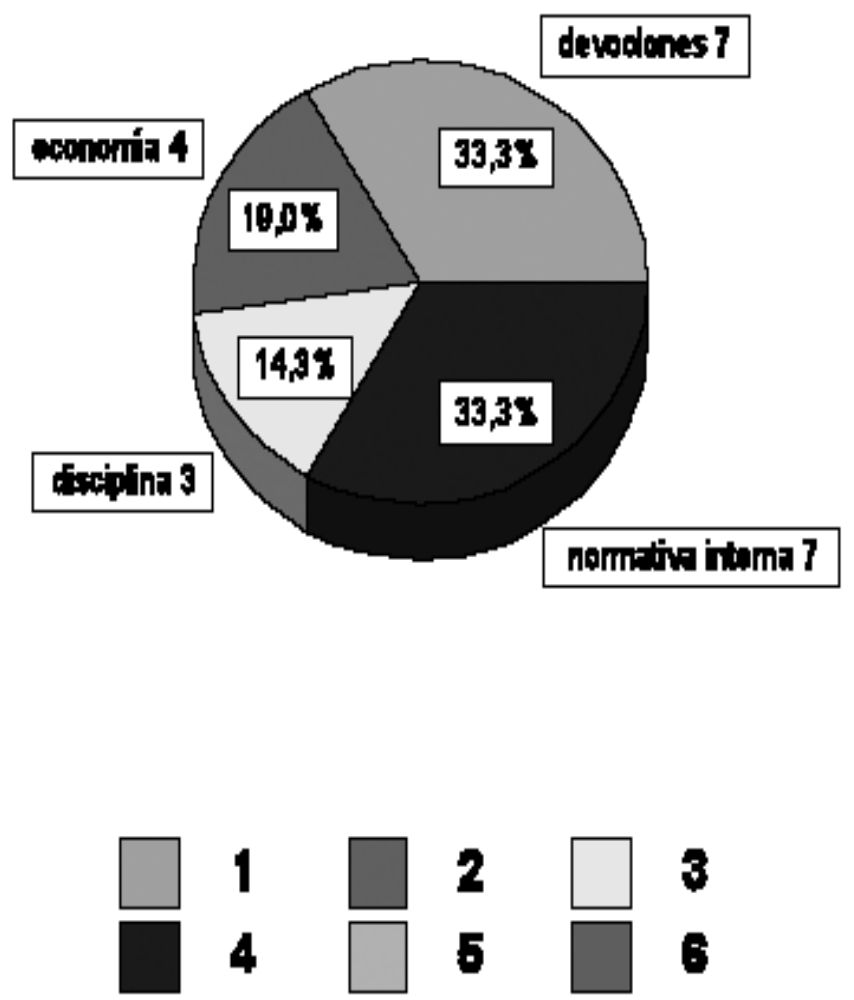

3

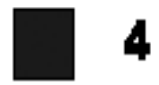

5

8

GRÁFICO 3. Fuente: Elaboración propia a partir de ADS, sig. 1486

Dios y buena horden». El texto refleja un traslado realizado en 1632 de una regla del siglo XVI, anterior a Trento.

${ }_{14}$ ADS sigs. 5538 , fols. $1-20$ y 6644 , fols. 5 r-18r : A modo de ejemplo, se pueden citar los casos de $\mathrm{N}^{\mathrm{a}} \mathrm{S}^{\mathrm{a}}$ de la Verguería en Lantueno (octubre de 1696) y $\mathrm{N}^{\mathrm{a}} \mathrm{S}^{\mathrm{a}}$ del Humano, en Población de Yuso (1 de febrero de 1699). 
Las cofradías en Cantabria: elementos para la comprensión de una estructura...

Así, introducciones como la de la Regla de Santa Marina del lugar de Valdeprado, representan un magnífico ejemplo al respecto que no deja lugar a dudas en cuanto a las intenciones fundacionales ${ }^{15}$, que siguen apareciendo de forma invariable, incluso en modelos más escuetos ${ }^{16}$.

La primera, y tal vez sorprendente, conclusión podría ser que en todos los casos, ya se trate de devociones generalizadas o de carácter local, los fines aparecen siempre con un alto grado de coincidencia (bien que no exento por completo de matices) en las declaraciones de principios. Esto sucede incluso en aquellos casos que, aún expresando en sus Introducciones regulares respectivas una voluntad especial de solicitud al santo patrón (como es el caso, por ejemplo, de la protección contra la pestilencia), revelan, no obstante, en sus artículos o cánones posteriores preocupaciones más que similares a las del resto ${ }^{17}$, sin que en nuestra opinión exista nada que nos autorice a dudar en términos razonablemente generales, ni de la sinceridad de los objetivos planteados ni de las intenciones fundacionales que se expresan.

Para demostrar de forma incontestable dicha homogeneidad, hemos intentado realizar una compilación cuantitativa exhaustiva de la totalidad de los mandatos que expresan los objetivos fundacionales de una serie de cofradías representativas. Así, se ha realizado un muestreo sobre 192 autos recogidos en las reglas fundacionales de 10 Cofradías cuyos mandatos han sido agrupados en 6 variables fundamentales. No se trata en principio de una tarea sencilla porque frecuentemente estos son difícilmente clasificables y no está claro cuando uno principal se

15 ADS, sig. 1486, fol. 4r y v: «In Dei Nomine Amén. Porque la vida de este mundo es breve a las criaturas humanas, porque es dicho por Job Quam breves sunt dies hominis. Por tanto continuamente deben estar los hombres humanos fortalecidos de buenos pensamientos y obras, pues nuestro Señor jamás hizo a los hombres para que muriesen manifestando en esto su grandeza y poderío, porque ninguna otra cosa tan fácilmente estorba ni quita a los humanos de pecar como la fuerte recordación de la muerte, como está dicho por S. Agustín: Nihil sic revocat a pecato sicut frequens meditatio mortis. Pues en lo dicho no hay dudas, razón será procuremos el fabor de la bendita Madre de Dios y Señora Nuestra, porque así como el sol no comunica sus rayos con la tierra, sin que antes y primero los comunique con el aire, así nuestro Señor a ninguno hace merced sin que antes y primero interbenga el ruego de su gloriosa Madre, como es doctrina de los santos doctores de la Santa Madre Yglesia, mediante el fabor de la cual y el ruego de la bienabenturada virgen Santa Marina, mediadora y favorable a los hombres que quieren lebantar sus corazones al serbicio de Nuestro Señor y a la devoción y regla de la sobredicha virgen Santa Marina, abogada nuestra. $Y$ por que nuestro fin y paradero sea la gloria del paraíso, como enseña la Santa Escriptura: Ay del solo, se cae y no hay quien le lebante, así mismo dice que a donde fueren dos o tres juntados en su nombre, en medio de ellos está él. Por estas cosas y otras muchas que de las Escripturas Santas se pueden colegir de los dichos de los Santos Padres a salvación y remedio de los vivientes y a sufragio de Las Ánimas difuntas, los hermanos cofrades de la Hermandad y Cofradía de la bienaventurada Santa Marina virgen, del lugar de Valdeprado [...] acordamos de hacer una ordenación y regla, por la cual todos serbiéremos a Dios Nuestro Señor y creciese en los humanos hombres más la deboción de la sobre dicha virgen [...]».

16 ADS, sig. 3730, fol. 1r y v.

17 ADS, sig. 4151, fol. 1r: Es el caso de S. Lorenzo de Pujayo, donde específicamente se señala: «En el nombre de Dios Todopoderoso, creador del Cielo y de la Tierra, Padre, Hijo y Espíritu Santo y de la gloriosa siempre Virgen Santa María y del bienaventurado S. Laurenzio a quien tomamos por patrón e interçessor y abogado para que por su ruego e interçessión merezcamos en este mundo ser favorecidos y libres de toda pestilencia y mal contajio y ser partiçipantes del Reyno de los Cielos. Amén». 


\begin{tabular}{|c|c|c|c|c|c|c|c|c|c|c|}
\hline ○ & 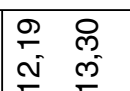 & $\begin{array}{l}\stackrel{Q}{N} \\
i n\end{array}$ & I & I & $\underset{10}{8}$ & $\begin{array}{l}0 \\
0 \\
0\end{array}$ & $\stackrel{8}{0}$ & $\stackrel{\infty}{\infty}$ & & 1 \\
\hline 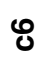 & $10 \sim$ & - & | & 1 & - & $\forall$ & - & $N$ & & I \\
\hline ১0 & 11 & I & 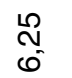 & I & I & I & 1 & व. & & I \\
\hline \& & 1 1 & I & - & 1 & | & | & | & - & & I \\
\hline ○ீ & 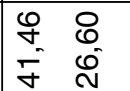 & $\frac{5}{n}$ & $\begin{array}{l}\frac{1}{R} \\
\infty \\
\infty\end{array}$ & $\begin{array}{l}\infty \\
\text { ల } \\
\text { N్ }\end{array}$ & $\begin{array}{l}8 \\
\text { م } \\
\text { N }\end{array}$ & 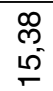 & 命 & : & & 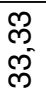 \\
\hline ठ & $\stackrel{\circ}{\circ}$ & 0 & $m$ & $\mp$ & م & $\sim$ & ल & - & & $\wedge$ \\
\hline$\circ^{0}$ & $\begin{array}{ll}1 & 0 \\
\infty & \varrho \\
\sigma^{-} & 0\end{array}$ & $\begin{array}{l}\stackrel{\varphi}{N} \\
\stackrel{N}{0}\end{array}$ & 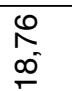 & $\begin{array}{l}\overline{0} \\
0 \\
0\end{array}$ & 8 & $\begin{array}{l}\infty \\
m^{\infty} \\
\rho^{\circ}\end{array}$ & $\begin{array}{l}8 \\
6 \\
10\end{array}$ & $\begin{array}{l}0 \\
\text { ल } \\
0 \\
0\end{array}$ & & $\begin{array}{l}\mathbb{D} \\
\stackrel{+}{\sim}\end{array}$ \\
\hline ช & $\sim-$ & - & $m$ & $\forall$ & - & $\sim$ & - & $\sigma$ & & m \\
\hline$\circ^{0}$ & 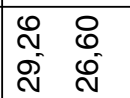 & $\frac{\stackrel{L}{O}}{\mathrm{~N}}$ & 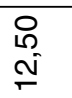 & 1 & $\begin{array}{l}8 \\
\text { O } \\
\text { ¿ }\end{array}$ & g & $\begin{array}{l}\hat{0} \\
\text { న్ }\end{array}$ & 1 & & $\begin{array}{l}\text { ठ } \\
\text { के }\end{array}$ \\
\hline ชิ & $\stackrel{+}{\cong}$ & $\nabla$ & $\sim$ & 1 & $\forall$ & - & $m$ & I & & $\nabla$ \\
\hline ○ீ & 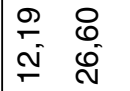 & $\begin{array}{l}\infty \\
\infty \\
0 \\
0\end{array}$ & $\begin{array}{l}\text { N } \\
\stackrel{\vartheta}{q}\end{array}$ & $\begin{array}{l}\hat{1} \\
\infty \\
\infty\end{array}$ & $\begin{array}{l}8 \\
8 \\
\qquad 5\end{array}$ & $\begin{array}{l}0 \\
\stackrel{0}{0} \\
0\end{array}$ & $\begin{array}{l}0 \\
\stackrel{+}{+} \\
\infty \\
\infty\end{array}$ & N & & $\begin{array}{l}\text { m } \\
\text { ले }\end{array}$ \\
\hline$\overline{0}$ & $10 \nabla$ & $\Lambda$ & $\Lambda$ & 0 & $a$ & 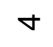 & ما & $m$ & & $\wedge$ \\
\hline 읋 & $\stackrel{\mathscr{8}}{\emptyset} \overline{0}$ & $\frac{+}{6}$ & 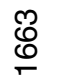 & 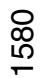 & જิ & స్త్ర & ठ্ণ & $\begin{array}{l}\hat{\infty} \\
0 \\
\end{array}$ & & \begin{tabular}{l} 
O \\
0 \\
\hdashline
\end{tabular} \\
\hline 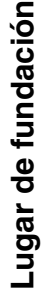 & 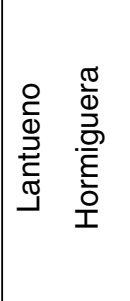 & $\frac{0}{\frac{0}{2}}$ & 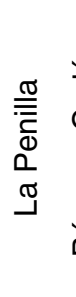 & 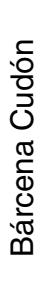 & $\frac{\stackrel{\circ}{\frac{\pi}{\sigma}}}{\frac{\pi}{\sigma}}$ & $\begin{array}{l}\frac{\pi}{2} \\
\frac{2}{5} \\
\frac{.0}{0} \\
\frac{\pi}{0} \\
\frac{0}{\pi}\end{array}$ & $\begin{array}{l}0 \\
2 \\
\frac{0}{2} \\
: \frac{1}{0} \\
\frac{0}{0} \\
\frac{\pi}{0} \\
0 \\
0\end{array}$ & $\begin{array}{l}\mathscr{W} \\
\mathbb{0} \\
\stackrel{0}{\mathbb{J}} \\
\text { త్ }\end{array}$ & & $\begin{array}{l}\frac{0}{0} \\
\frac{\pi}{2} \\
\frac{0}{0} \\
\frac{0}{\pi}\end{array}$ \\
\hline 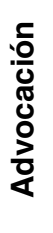 & 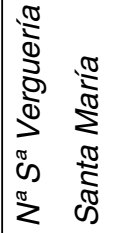 & 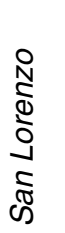 & 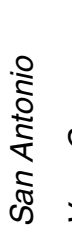 & 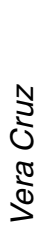 & $\begin{array}{l}0 \\
\frac{0}{0} \\
0 \\
0 \\
\frac{1}{\pi} \\
\text { ஸे }\end{array}$ & $\begin{array}{l}\overline{0} \\
\frac{\pi}{2} \\
\frac{0}{0} \\
\pi \\
0 \\
\frac{\pi}{2}\end{array}$ & 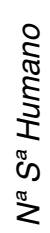 & 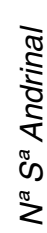 & & 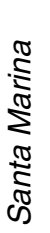 \\
\hline
\end{tabular}

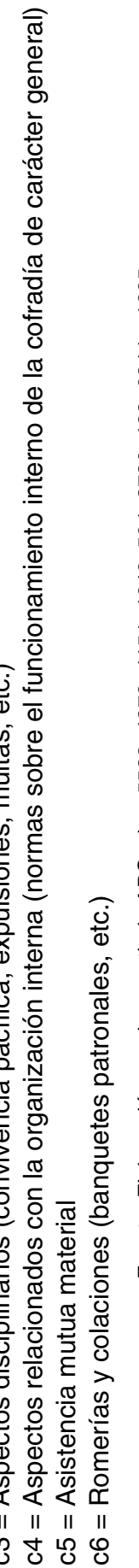


desglosa en otros de carácter secundario. Entendemos, de todas formas, que se trata de una aproximación muy válida para determinar la intencionalidad inicial de los fundadores y, en definitiva, los aspectos sobre los que esencialmente incidía el interés a la hora de erigir una de estas agrupaciones. Al menos en teoría. Los mandatos determinan (especialmente si tenemos en cuenta que la mayor parte de los estudiados se hacen presumiblemente sobre otras reglas muy anteriores) la vida cotidiana de la cofradía, con sus diferentes objetivos, situaciones y problemas. Este es el resultado a partir de las siguientes claves (ver CUADRO 2).

Así, las declaraciones de intención y los objetivos iniciales quedarían según los valores totales en un $32,27 \%$, que se asignaría a los aspectos devocionales, un $15,91 \%$ a las ordenanzas de tipo económico, un 13,33\% a las cuestiones disciplinarias, el $27,66 \%$ a los aspectos de normativa interna, tan sólo el 1,4\% a las disposiciones de ayuda mutua y un $9,23 \%$ a la regulación de actividades comensalísticas y romerías. Naturalmente, podría objetarse la metodología empleada afirmando que el número de disposiciones dedicadas sobre el papel a la regulación de un determinado tipo de aspectos no tendría por qué corresponderse con la importancia inicial que a éste se le diera, siendo así que algunos de ellos, por sus características determinadas, precisarían de mayor cuidado aunque fuesen en la realidad de importancia inferior a otros, más sencillos de legislar, pero de mayor relevancia en el desarrollo concreto de las actividades normales de la hermandad. Sin embargo, aunque esto pudiera ser válido para algunos aspectos como la economía, la disciplina o la normativa interna diversa, difícilmente podría ponerse como excusa para objetar el enorme desnivel que existe entre la voluntad primordial puramente devocional, con su $32,27 \%$ de los autos registrados, frente al $9,23 \%$ de las actividades de carácter más lúdico y un ínfimo 1,4\% de disposiciones encargadas de gestionar la ayuda mutua.

Realmente es solo una aproximación, tal vez la única, que podemos hacer, pero tiene, a nuestro entender, un alto valor gráfico sobre la intencionalidad de los fundadores de la hermandades sodalicias cántabras. Por otro lado, no es indiferente el hecho de que los ejemplos escogidos sean, salvo un caso (bien antiguo, por lo demás), representantes de lo que podríamos llamar «congregaciones locales», no generalistas (como podrían ser El Rosario o Las Ánimas, mucho más homogéneas, quizá también de menor sustrato popular) y de iniciativa no regular, es decir aquellas en las que la mentalidad local tendería obviamente a expresarse con mayor contundencia o claridad. Y ésto es algo que no sucedía, pues parece que en la Edad de Oro fundacional de las cofradías cántabras, incluso aquellas más sospechosas de esconder bajo su canónica forma un reducto de actividades non sanctas desde el punto de vista de los valores de la confesionalización, estuvieron ganadas, al menos en la superficie, por ideales muy cercanos a éstos.

Es preciso, pues, resaltar estas dos aseveraciones importantes. La primera es la gran homogeneidad teórica que estas instituciones presentaron, tanto en sus objetivos iniciales como en las disposiciones y normativas de que se dotaron e igual- 
mente, en los fines básicos que se propusieron alcanzar (más aún, podríamos decir que incluso sus desviaciones y problemática fueron generalmente similares). Asimismo, es cierto que en determinados casos, como el de las penitencias públicas, sí podemos encontrar diferencias entre quienes las practicaban y aquellas que no lo hacían. No obstante, nos da la impresión de que, salvando el dramatismo evidente que esta práctica imprimía a toda la hermandad sodalicia, el fondo devocional era sustancialmente el mismo, y de ello da tal vez prueba el paso progresivo de «espiritualización» del castigo penitencial que las cofradías de flagelantes van a ir experimentando a partir del fin del siglo XVII, con una fuerte disminución del número de «hermanos de sangre».

La segunda es nuestra inclinación a pensar que dichas asociaciones nacieron con una inquietud claramente espiritual ${ }^{18}$, es decir, que frente a las teorías que han intentado ver en los últimos años a las cofradías como lugares en los que se refugiaría la antigua religiosidad popular pre-cristiana, o cristiana reticente a los postulados tridentinos, a modo de células de resistencia de una piedad subalterna, por contraposición a las directrices elitistas, hemos de afirmar que más bien fueron elementos de penetración de éstas sobre aquella, si es que podemos conceder cierta validez a ambos calificativos. El fin primordial de las cofradías fue asegurar la salvación eterna.

Ahora bien, ¿de quiénes partieron en esencia las iniciativas fundacionales?, ¿quiénes dirigieron y ejercieron el control de las hermandades, después? éstas son preguntas importantes y plantean un interrogante clásico en cualquier debate de historia social. Así, hay que dejar bien claro desde un principio que las asociaciones sodalicias no hubieran podido tener el menor éxito de no haber contado con un firme y continuado apoyo de sus miembros más comunes, siendo absurdo pensar en un «instrumento de uniformización» impuesto durante tanto tiempo contra la voluntad de sus miembros. Por consiguiente, no parece razonable dudar de que dichas instituciones fueran, de una manera u otra, el resultado de una voluntad popular clara y determinada, como claramente se expresa en numerosos autos fundacionales.

En esta afirmación general hay matices. Para empezar, hay que señalar que en el caso de las hermandades más antiguas, y en el de aquellas otras que per-

${ }_{18}$ Sin que el término «espiritual» nos mueva a engaño, no cabe duda de que el éxito de las cofradías estuvo más que nada enraizado en el interés que sus ofertas espirituales, convivenciales y comensalísticas despertaron en amplias capas de la población. Ahora bien, es probable que una mentalidad religiosa elitista (en especial una mentalidad elitista tridentina «de primera generación») tendiera a considerar incompatibles estos diferentes aspectos. No creemos que para las clases subalternas del Antiguo Régimen sucediera lo mismo, por lo que no debemos de caer en un error parecido nosotros también. Es ciertamente difícil saber qué fue a la larga más importante para quienes se inscribían como hermanos en una cofradía, si los beneficios espirituales propiamente dichos, el sentido de pertenencia a un grupo de consolidación en términos sociales, el prestigio personal ante la comunidad (pensemos en el caso de los penitentes o, incluso, de los alumbrantes) o el festín que tenía lugar con ocasión de la fiesta patronal. Lo que tal vez no nos sea lícito es ver la coherencia, desde nuestra mentalidad en términos de exclusión de contenidos, cuando en la popular no existía tal vez más que una simple gradación. 
tenecen a advocaciones puramente locales (ligadas a centros devocionales particulares), es muy difícil saber en realidad quién o quiénes, concretamente, estuvieron detrás de la erección de cada fundación particular. Fuera de la documentación que la propia institución generaba no suelen existir otras fuentes de información y muchas veces falta la parte inicial de los libros (la más expuesta a deterioro), que es donde suele darse la noticia, más bien escueta, acerca de la identidad de los promotores. Dicho ésto, hay indicios suficientes como para volver a recalcar la idea con la que finalizábamos el párrafo anterior, es decir el hecho de que en muchos casos parece existir siempre una voluntad popular que desea, impulsa y asume en mayor o menor medida el proyecto inicial, integrándolo después en la vida cotidiana de su comunidad, frecuentemente por largo tiempo ${ }^{19}$. Incluso se diría que los congregantes tiene intención en destacar la pureza de su intención y la libertad y voluntad que generan su iniciativa ${ }^{20}$. Por otra parte, sí es frecuente (especialmente a partir del siglo XVII) que sea un sacerdote el que encabece una iniciativa o una refundación. No obstante nunca aparece sólo²1.

19 ADS, sig. 540, fol. 1r. Demos la palabra a los documentos y comencemos por uno de fecha tan temprana como 1580. El testimonio que da origen a La Vera Cruz de Bárcena de Cudón: «En el Nombre de la Santísima Trinidad, Padre, Hijo y Espíritu Santo, tres personas distintas y un solo Dios verdadero, sin el qual ninguna cosa tiene buen fin ni principio, el qual todo fiel christiano debe creer fielmente, y en el nombre de la santa Cruz y Cofradía y en rremembranza de la Muerte y Pasión de nuestro Señor Jesuchristo, que rrecevió en el árbol santo de La Vera Cruz, por salbar a todos los perdidos, y por ende, manifiesto sea y notorio a todas las personas que la presente vieren, como el Concexo de Bárcena de Cudón, deste arçobispado de Burgos, como en este año de mill y quinientos y ochenta, nos juntamos Miguel Fernández de Corona, Pedro Fernández de Vallejo, Juan Gutiérrez de la Pila, Fernando Fernández de la Torre, Torivio de Herrera, Torivio de Rumoroso, y dijeron que estos están convenidos de un acuerdo y voluntad de ser de la Cofradía y Hermandad de la Santa Vera Cruz. Y que no lo hacían por vanidad ni vanagloria, ni por que las xentes tuviesen qué decir, sino por servicio de Dios Nuestro Señor y en rreverencia de la muerte y Pasión que rrescevió en el árbol de La Vera Cruz. Para que tenga cumplido efeto capitularon y ordenaron los capítulos y órdenes siguientes para que tan Santa Cofradía, vaya desde aquí adelante en aumento y no benga en disminución y sea bien rregida [...]».

${ }_{20}$ ADS, sig. 4378 , fols. $3 v$ y 4 r. Una voluntad popular que puede percibirse con la misma claridad entre las líneas del auto fundacional de Santa María de Hormiguera, donde tras una interesante Introducción señala: «Los hermanos confrades de la hermandad y confradía de Nuestra Señora Sancta María [...] de Hormiguera y hermanos de la dicha confradía de Nuestra Señora Sancta María hermita del dicho lugar acordamos de haçer una ordenaçión y regla por la qual Dios fuese mas servida y creciese en los humanos hombres más la deboción de la sobredicha Virgen [...]». No se trata de una excepción. En Santa Marina de Valdeprado, se expresa como «[...] los cofrades acordamos de hacer una ordenación y regla por la cual todos sirbiéremos a Dios Nuestro Señor», sin más especificaciones de individualidad ni rango. Más adelante «darán y otorgarán poder» a dos clérigos para que acometan la «reformación» de los capítulos (lo cual era absolutamente lógico, aunque solo fuese por razones de competencia profesional), pero queda claro que son los cofrades, efectivamente, los dispensarios de esta potestad (ADS, sig. 1486). Un caso similar es que hallamos en la cofradía de Nuestra Señora de la Verguería de Lantueno, donde, en 1696, se encarga a una comisión mixta, formada por el abad (que es el párroco) y algunos cofrades más «hazer, ordenar y decretar orden y regla para el gobierno, aumento y conservazión de la dicha cofradía» (ADS, sig. 5538, fols. $1 \mathrm{r}$ y $2 \mathrm{v}$ ).

${ }_{21}$ ADS, sig. 6844 , fol. $5 r$ y v. Es lo que sucede, por ejemplo en el caso de la cofradía de Nuestra Señora del Humano en la Población de Yuso, donde a la hora de presentar a los capítulos de «ynstituçión y fundaçión» señala como protagonistas a «[...] nos el licenciado D. Juan Sáiz de Collantes, presvittero cura y venefiçiado en estte dicho lugar, vicario por el señor arçediano de Treviño, en todo su arçedianatto, abbad de dicha cofradía, Don Juan (González?) De Collanttes, Don Fernando Sigler de Bustamantte, Juan Gutiérrez del Varrio y Juan González de Somavilla [...]». 
Por lo que respecta al caso de las hermandades promovidas por las órdenes religiosas, que alcanzaron su cenit en la época post-tridentina, éste presentó matices diferentes. Ya hemos hablado de ellas con anterioridad y, según se ha visto, fueron las más numerosas y sin duda las más influyentes dentro del amplio espectro de la piedad asociativa de ese tiempo. Las confraternidades de inspiración regular estuvieron directamente relacionadas con la actividad misionera de los frailes y han de verse como una continuación de la misma o, mejor dicho, como una consolidación de los conceptos, valores, normas y pautas de comportamiento que en aquella habían sido expuestos en primera instancia. La fundación revestía un carácter más solemne y ensayado, perfectamente elaborado y repetido con profusión. Sin embargo, este tipo de instituciones ostentaba un estatuto jurídico que las ligaba de alguna manera a la Orden a la que estaban vinculadas. Esto, al menos, es especialmente claro en el caso de El Rosario, sin duda alguna la más cercana a los presupuestos del proceso de confesionalización de todas ellas. En efecto, la Orden de Predicadores otorgaba, como se ha visto anteriormente, la licencia que se daba al fraile fundador (o mejor dicho, tal vez, promotor) de la entidad, a fin de que la misma cumpliese los requisitos generalmente solicitados, y así los cofrades pudieran beneficiarse del enorme caudal de indulgencias y otros bienes espirituales que la pertenencia a la misma comportaba. No cabe duda, pues, de que el control de las mismas (por lo menos en una primera instancia) fue grande por parte de los conventos a cuya jurisdicción pertenecían ${ }^{22}$.

Las normas quedaban, en todo caso, perfectamente especificadas en ellas, así como en sus libros fundacionales encontramos un rigor teológico y conceptual lógicamente mucho mayor que en las fundaciones locales. Todos los detalles estaban previstos y fijados (desde instancias muy altas), a través de los cuales la Orden deseaba mantener un control estricto de una fundación que, según podemos ver, difería sustancialmente de las hermandades de base local. Al menos en teoría, porque una vez finalizado el ritual y vueltos los frailes a sus casas, ¿podían permitirse los conventos (con la sobrecarga de trabajo existente en algunos y su proverbial escasez de miembros) ocuparse de la dirección espiritual de un número tan desorbitado y disperso de fundaciones? Nos resulta difícil de creer. Con todo, no hay duda de que su idea particular de evangelización, netamente tridentina, pudo calar de alguna manera dentro del pueblo de Cantabria. Y así debió ser, seguramente, pero tampoco es razonable dudar de que los principios expresados en la iniciativa fundacional hubieron de mezclarse, forzosamente, tanto con las claves devocionales populares como con las directrices pastorales del clero secular, a quien, en última instancia, quedaba confiada (al igual que sucedió con las hermandades locales), la marcha cotidiana de la cofradía. Y, siguiendo esta orienta-

${ }^{22}$ ADS, sig. 884, fol. 5r.Ya se ha visto el caso concreto de Las Caldas, sin embargo, debió de tratarse de un fenómeno generalmente extendido, puesto que sabemos que, a principios del siglo XVII, el prior de un convento tan distante como San Raimundo de Potes poseía la facultad de confirmar o no la fundación de El Rosario situada en Proaño (Campóo), aunque algún tiempo después esta capacidad de confirmar residía en un simple fraile «residente» en dicho convento. 
ción, permítasenos la insistencia en recalcar que fue aquí también y en última instancia la voluntad popular (fuesen cuales fuesen sus motivaciones para ello) la única y verdadera garante de una historia institucional, plurisecular en muchas ocasiones, al integrarla satisfactoriamente tanto en el horizonte personal de cada individuo como en el de la propia colectividad.

Así pues, es preciso comprender que las iniciativas fundacionales de estas instituciones tuvieron, al menos, cuatro promotores importantes, de diferentes rangos y en distintos niveles: Primero, las jerarquías diocesanas, que vieron en ellas un medio eficaz de transmisión de los postulados confesionalizadores, una forma de ir convirtiendo las antiguas expresiones populares de devoción, cargadas de matices poco ortodoxos, en las nuevas formas de vivencia y expresión de la fe que demandaban los tiempos tras el Concilio, y ello con un encuadramiento decididamente parroquial. Ésto nos parece un asunto de suma importancia, porque este pequeño detalle revela, tal vez, la precaución por sacar de ese ámbito cultural subalterno, percibido como peligroso por el cristianismo de élites, el ámbito de la práctica devocional cotidiana. Es decir, no es más que un pequeño ejemplo de un proceso desarrollado posiblemente a gran escala y a lo largo de siglos. Así, las condiciones y desarrollo de ese proceso, los puntos de fricción y confluencia, las componendas, las presiones, las resistencias y las realidades polisignificativas a que dio lugar, todo ello se nos revela como uno de los aspectos más relevantes y menos estudiados de la evolución de la humanidad y de la génesis de la sociedad actual, con unas derivaciones que trascienden con amplitud el ámbito de lo estrictamente religioso. Por otro lado, no cabe duda de que en ese campo se jugó una de las evoluciones más determinantes del catolicismo popular y de la génesis de la compleja religiosidad española contemporánea.

Segundo, las órdenes religiosas, y en especial los dominicos, contemplaron la creación de hermandades (y Tercera Orden, aunque no desde luego en la misma forma, ni para las mismas personas) como un medio de llevar el evangelio, tal y como ellos lo entendían, a una región cuya pobreza en contenidos religiosos ortodoxos no pudo por menos que escandalizarles a su llegada. Los dominicos de Cantabria estuvieron fuertemente imbuidos del ideal tridentino en una versión rigorista y el marco de la cofradía de El Rosario fue un ámbito de encuentro, fuertemente normativizado, con unas masas rurales muy ajenas a sus principios intelectuales pero con una capacidad interactiva admirable en la percepción de ciertos contenidos simples y, sobre todo, de ciertas prácticas devocionales. Y no cabe duda de que para ellos constituyó un gran éxito, una manera de consolidar sus otras iniciativas pastorales (la misión, la confesión, la dirección espiritual y, por supuesto, la predicación) y la única que no necesitaba su presencia continua, muy comprometida.

Tercero, el clero secular. En efecto, el clero regular para conseguir sus propósitos necesitó la ayuda de este tercer elemento promotor de las cofradías. Y si bien es cierto que el clero secular no necesitó muchas veces de los regulares, como se ha descrito en el caso de las hermandades sodalicias de base local, está claro, no 
obstante, que la mayor parte de los clérigos no fueron capaces, o no quisieron erigir y dotar teológica, administrativa y pastoralmente unas fundaciones que hicieran las veces entre sus feligresías respectivas. Ello explica la acogida aparentemente buena que tuvieron las cofradías de El Rosario en tantas parroquias. Dicha institución ofreció un esquema perfectamente estructurado y desarrollado, sus prácticas eran claras y sus beneficios espirituales detallados y autentificados. En definitiva, significaba una buena oportunidad, no demasiado complicada, para aquellos sacerdotes seculares deseosos de evangelizar de alguna manera en sus comunidades. No cabe duda de que, en cierta manera, esta entidad reforzó las relaciones del binomio cura-feligreses con el de abad-cofrades y, además, supuso un importante punto de encuentro (y por tanto de influencia) entre ellos y aseguró la adquisición, al menos teórica, de unos contenidos, actitudes y procedimientos prácticamente inconquistables de otro modo. Además, es posible que la hermandad ayudara a reforzar la figura del cura-abad en el conjunto de la relaciones sociales de la comunidad rural. Por otro lado, la dependencia del «convento más cercano de la Orden de Predicadores» fácilmente se observa como algo más teórico que real, pasada la etapa propiamente fundacional. Todas estas características explican, sin duda, la aceptación de la hermandad por parte del clero secular y su consiguiente éxito en tantos lugares. Evidentemente, las relaciones de los sacerdotes de las parroquias con los dominicos (y con el resto de las órdenes religiosas) no fueron siempre buenas, lo que tal vez pudiera explicar, en parte, por qué la mayoría de las parroquias de Cantabria se quedaron sin cofradías de El Rosario, de $\mathrm{La}$ Vera Cruz y de otras. Un sector del clero secular, aunque escaso, prefirió desarrollar y adaptar a las nuevas normativas eclesiásticas post-tridentinas las antiguas instituciones de base local o fundar agrupaciones en torno a una devoción particular comunitaria.

Cuarto, los propios laicos, que constituyeron sin duda un factor decisivo. Las cofradías fueron instituciones seculares, que estructuraron de alguna manera la fe y la práctica devocional de generaciones enteras. Nada de ésto hubiera sido posible si dicha forma de piedad asociativa no hubiera encontrado un fuerte punto de anclaje en algún lugar del alma popular. Lo cual no excluye, de ninguna manera, que no se diera un fuerte componente sociológico en el hecho de pertenecer a una o varias hermandades ${ }^{23}$.

Lo anteriormente expuesto, nos permite poner en cuestión la idea que ha venido presentando a estas instituciones como algo «impuesto desde fuera» y con un fin «aculturador». Es evidente que las élites religiosas utilizaron a las cofradías

${ }^{23}$ En los testamentos estudiados en el lugar de Miera (1651) todas las mujeres que otorgan su última voluntad afirman pertenecer a más de una hermandad. Este hecho no es irrelevante, pues indica un muy alto grado de aceptación y solapamiento social de la institución. Podríamos establecer incluso una correlación con el hecho que lleva, aún hoy, a numerosas personas a cumplir con ciertas prácticas sacramentales muy estandarizadas (bautizos, primeras comuniones, bodas y funerales), sin que éstas se vean reflejadas ya en unos contenidos mínimos de devoción personal explícita. Pero en el siglo XVII las condiciones no eran en absoluto similares y dicha imbricación, entre lo socialmente conveniente y la creencia personalizada, no tenía por qué significar menoscabo para ninguna de ambas. 
como un elemento introductor de su mensaje religioso, pero no es menos cierto que éste fue aceptado y asimilado de la forma que cada grupo y persona consideró más conveniente para sus intereses religiosos, sociales o de otro tipo. Dicho en otras palabras, y para resumir, éstas instituciones cubrieron con un grado diverso de eficacia una necesidad real existente (aunque, en cierto sentido, estimulada desde fuera) en las clases subalternas, de ahí que éstas las apoyaran con bastante decisión y por eso tuvieron éxito. Huelga decir, finalmente, que no puede entenderse dicho éxito, aunque sea relativo, sin comprender la unidad, o tal vez mejor dicho la confluencia de intereses que existió entre estos cuatro promotores.

Pasemos ahora al gobierno de estas instituciones, que tuvo características variables. En las de El Rosario, como ya se ha puesto de manifiesto, el fraile fundador debía nombrar algún sacerdote (normalmente el propio párroco) como capellán sobre el que recaía, en su función de letrado, la obligación de inscribir a los hermanos que fuesen incorporándose, así como los aspectos pastorales y litúrgicos propios de su estado ${ }^{24}$. Por otro lado, el propio capellán detentaba también la responsabilidad de presentar anualmente al prior del convento dominico más cercano la lista de los nuevos hermanos, con lo que quedaba resaltado que era éste quien finalmente ejercía el control y potestad última de la institución, aunque fuese en la práctica sólo de forma nominal. Los cofrades fundadores podían entonces elegir algunas personas «prinçipales y debotas» para el cargo de oficial. Según el número y la dispersión de la institución en cada pueblo, era necesario el nombramiento de un prioste y dos o tres mayordomos ${ }^{25}$.

Desde luego, existieron otras formas. En la cofradía de Santa Marina de Hormiguera, a principios del siglo XVII, todos los hermanos daban facultad a Fernando González «por virtud de un Poder que le otorgaron todos los vezinos de el lugar de Hormiguera hiciese y aprovase esta dicha Regla y capítulos», que incluye el nombramiento de abad (el cual recae en el párroco del lugar, Juan Rodríguez de Dosal). Es éste quien debía con posterioridad efectuar el nombramiento de oficiales: prior y capiscol, mayordomo, alcalde, merino, muñidor, etc., con la facultad de removerlos de sus cargos cuando le pareciere oportuno. A la muerte del abad había de sustituirle el cura siguiente del lugar, siempre y cuando (esto es muy importante) no fuese rechazado por los oficiales y el pueblo, quienes se reservan en última instancia la facultad de buscar otro candidato más conveniente ${ }^{26}$.

Sin embargo, en otras hermandades, la importancia del Abad o capellán parece declinar en favor de la figura del Hermano Mayor $^{27}$, el cual estaba obligado a

\footnotetext{
${ }^{24}$ Siempre, eso sí (es importante recalcarlo): «en su ausenzia [del padre fundador] y de otros frailes de santo Domingo" y de forma gratuita.

${ }_{25}$ ADS, sig. 5567, fols. 31r-32v. En la cofradía de El Rosario de Bárcena de Cicero, las mujeres organizaban una cierta "sección femenina» con una priora y dos compañeras más que organizasen trabajos de limpieza y logística.

26 ADS, sig. 4378, fols. 4v-5v.

27 ADS, sig. 4646, fol. 4r. Es el caso de la cofradía de San Pedro en La Penilla, donde, en las constituciones realizadas el 8 de octubre de 1662, se establece que este cargo sea de elección entre los
} 
aceptar dicha elección so pena de dos ducados ${ }^{28}$, siendo frecuente la alusión a esta «obligación» de aceptar los cargos, lo que quizá nos da una prueba de que los elegidos no lo eran siempre de excesivo buen grado. Incluso, en algunos casos llega a especificarse el derecho a la exención de responsabilidades para aquellos que las habían detentado con anterioridad en alguna ocasión ${ }^{29}$. En otras ocasiones parece existir una especie de potestad compartida entre laicos y clérigos, como se puede comprobar fácilmente en la cofradía de Nuestra Señora del Humano, cuya detalladísima regla menciona en varias ocasiones una cierta responsabilidad conjunta del Abad y los mayordomos ${ }^{30}$. En todo caso parece claro que, en algunas ocasiones, el cargo máximo de Abad podía ser ocupado por personas laicas, cuya autoridad y autonomía fueron notables ${ }^{31}$.

Finalmente, podríamos concluir diciendo que, tanto la iniciativa fundacional como el gobierno de las cofradías, fueron aspectos que presentaron una amplia variedad de posibilidades. Una vez más debemos señalar las diferencias entre los distintos tipos de fundaciones, haciendo hincapié en la diversidad existente entre aquellas sociedades antiguas, ligadas al culto local (que, según indican varias reglas intentaron realizar un cierto aggiornamento, tras el Concilio, para adecuarse a las nuevas directrices eclesiales y diocesanas) y las que eclosionaron en el más puro estilo de la confesionalización tras Trento. Las primeras, presentan lo que podríamos llamar un claro espíritu laical, están ligadas a la devoción popular y se hayan fuertemente enraizadas en ella. Las segundas, aparecen protagonizadas y promovidas, probablemente, por un sector escogido del clero (tanto regular como secular) y reflejan a la perfección los nuevos aires del catolicismo. En ellas, el papel del sacerdote es mucho más significativo y esta importancia no hará más que aumentar a lo largo del siglo XVII. Si bien éstas hipótesis deberían ser ahondadas y matizadas en una monografía exhaustiva, creemos que nos indican con verosi-

miembros «[...] ocho días antes de la festividad se junten a cavildo todos lo[s] ermanos, sin que falte nayde y nombren ermano mayor a gusto de todos [...]»

28 Ibidem.

29 ADS, sig. 6844, fol. 14r. Por ejemplo, en la cofradía de Nuestra Señora del Humano en la Población de Yuso, se dice de los mayordomos: «[...] y a los que por una vez ayan servido y usado y açetado y dado quentta con pago de sus maiordomías que a estos ttales no se les pueda ni deva encargar ottra vez el tal ofiçio de maiordomos, sino que sea a falta de cofrades de las calidades dichas [...]".

30 ADS, sig. 6844.

31 ADS, sig. 488, fol. 5v: «[...] Ordenaron que cada un año, Víspera de nuestra Señora de Agosto, que es el día de la Asunción, todos los hermanos y Cofrades vayan a la iglesia de Nuestra señora santa María, Señora de El Moral, con el clérigo Capellán, que para ello fuere señalado, a la hermita de Nuestra Señora Santa María de Moral, y los hermanos cofrades que fueren impedidos pidan liçençia al abbad y maiordomos para se quedar [...]». En efecto, en la cofradía de Nuestra Señora del Moral de Riovaldiguña (probablemente a finales del siglo XVI) se hace una contundente declaración (que refuerza más el argumento de la tradición democrática expuesto líneas arriba) sobre el alcance y origen de la autoridad de este cargo: «[...] Es tanta la autoridad y mano de esta (sancta?) Hermandad que, conforme a las reglas antiguas, pueden los dichos cofrades, siendo su abbad (remiso?) Xristiano o escandaloso deponelle y nombrar otro a su voluntad, y lo mismo se entiende con los demás oficiales [...] Tienen mucha obligación todos los cofrades a venerar y respetar a su abad, siendo tal, tanto por lo que toca a esta dignidad, quanto porque ellos querrán que se haga con ellos quando les tocare». 
Las cofradías en Cantabria: elementos para la comprensión de una estructura...

militud la evolución en el origen y en el gobierno de las hermandades sodalicias montañesas de los siglos XVI a XVIII.

En este apartado sobre el gobierno y el control de estas instituciones, quedaría por determinar el papel real que jugó la alta jerarquía eclesiástica, que tan propicia se mostró, en general, a la promoción de las mismas, ya que en sus manos descansaba, en última instancia, el control supremo de estas asociaciones de piedad. $Y$ de hecho, éstas fueron muy «visitadas». No podemos, desde luego, esperar que tales inspecciones se llevaran a cabo con el cuidado empleado (al menos en teoría) en el caso de instituciones mucho más importantes como la parroquia, pero no puede decirse en absoluto que, una vez fundadas, la jerarquía secular se desentendiese de ellas. EI CUADRO 3 muestra la periodicidad de algunas de las llevadas a cabo en diferentes hermandades a lo largo del siglo XVII, a partir de las consignaciones de las mismas que quedan recogidas en sus propios libros).

CUADRO 3. Algunos años de visita en las cofradías de Cantabria.

\begin{tabular}{|l|l|l|}
\hline \multicolumn{1}{|c|}{ Lugares } & \multicolumn{1}{|c|}{ Advocación } & \multicolumn{1}{c|}{ Años } \\
\hline Bárcena de Cicero & Rosario & $1610,1611,1621,1625,1629,1633,1636$, \\
& & $1638,1640,1653,1656$, \\
\hline Pámanes & SS ${ }^{\circ}$ Sacramento & $1619,1621,1625,1656,1668,1672$ \\
\hline Bárcena de Cudón & Vera Cruz & $1608,1640,1650,1655,1657,1660,1663$, \\
& & $1665,1668,1671,1677,1680,1690,1699$ \\
\hline Hormiguera & Sta. María & 1658 \\
\hline Arnuero & $N^{a} S^{a}$ Candelas & $1610,1617,1619,1621,1623,1625,1629$, \\
& & $1631,1633,1636,1638,1640,1672,1676$ \\
\hline Valdeiguña & $N^{a} S^{a}$ del Moral & $1692,1714,1718,1723,1792$ \\
\hline Proaño & Rosario & $1658,1659,1663,1665,1668,1671,1680$, \\
& & 1690,1698 \\
\hline Entrambasaguas & San Antonio de Padua & $1680,1690,1698$ \\
\hline Ontoria & Rosario & $1665,1671,1677,1680,1690,1702,1705$, \\
& & $1709,1713,1719,1724,1728,1731,1741$, \\
& & $1744,1747,1750,1753,1757,1762,1764$, \\
& & $1802,1815,1831,1835$ \\
\hline Matamorosa & Rosario & $1714,1719,1723,1728,1737,1741,1744$, \\
& & $1747,1750,1753,1757,1762$ \\
\hline Nestares & San Antonio Abad & $1668,1671,1680,1692,1698$ \\
\hline
\end{tabular}

Fuente: Elaboración propia a partir de ADS, sigs. 540, 5567, 4378, 5538, 1756, 4355, 3857, 5729, 884, 4151, $488,6293,3628,5229$ y 2831. 
La frecuencia fue, como se puede apreciar, considerable para la época. Sin embargo, no es mucha la información que se puede extraer del contenido de sus actas. Ciertamente, hay una serie de temas-eje que se repiten con una continuidad y uniformidad que a veces parecen atemporales. Así por ejemplo, en las más de 100 visitas que aparecen en el citado cuadro (que recogen todo el siglo XVII en el conjunto de los casos y llegan hasta el XIX en dos de ellos), se pueden rastrear unas tipologías institucionales muy diversas (devota, numérica y geográficamente hablando), y es significativo que se encuentre un número muy limitado de correcciones (para nuestra desgracia, ya que son éstas las que nos informan principalmente de las desviaciones a la norma establecida y, por tanto, conocida). Generalmente conciernen a temas como las etiquetas en las ceremonias ${ }^{32}$, las advertencias contra quienes se arrogan un derecho injustificado de visita ${ }^{33}$, y las que intentan corregir los excesos producidos en los gastos, tanto por colaciones (con diferencia, las más numerosas) ${ }^{34}$, como en dispendios que ocasionan poca predisposición para aceptar el cargo de mayordomo ${ }^{35}$, mientras que también se da

${ }^{32}$ ADS, sig. 488, fols. 35v-36r. Como sucede en la visita realizada a la cofradía de Nuestra Señora del Moral de Riovaldiguña de 1692 (la única consignada en todo el siglo) y en la que el inspector anota: «Otrossí, fue su merced ynformado que sobre ofrezer y besar la mano al prestte el día de la festtibidad de Nuestra Señora, tienen sesión y dependençia entre el abbad y juez hordinario, y por que las cofradías son y se fundan para honrra y gloria de Dios y bien de las almas, y no para que se orijinen autos ni pecados, mandó su merçed a el abbad [...] no sse yntrometa en dicha pretenssión, hasta que ofrezca el juez y alcalde».

${ }^{33}$ ADS, sig. 3857, fol. 13r. Así sucede en Nestares de Campóo. En la visita de 1680 se denuncia la «intromisión» del abad del convento de los premonstratenses de Aguilar de Campóo, inspeccionando el libro de la cofradía de San Antonio Abad, para lo que se asegura no tiene jurisdicción «ni le toca más de nombrar capellán, sacerdote secular o regular, que sirva dicha yglessia y aprovado por el ordinario eclesiástico de este arçopbispado, a quien privativamente toca hacer dicha vissita y todo lo demás tocante al gobierno y administrazión de esta cofradía y a los señores sus vissittadores».

${ }^{34}$ ADS, sig. 6293, fol. 45r. Ya en la visita de 1638 a la cofradía de Nuestra Señora de Las Candelas en Arnuero se señala: «[...] de aquí adelante no gasten ni consuman las rentas ni limosnas de dicha cofradía en comidas ni bebidas, ni en gustos profanos, antes bien en çera y misas por los hermanos difuntos cofrades».

Por otra parte, en la cofradía de El Rosario de Bárcena de Cicero, el visitador (principios del XVII?) manda que «[...] ni se hagan juramentos ni se coma ni veba por quenta de los bienes de la cofradía [...] y las penas [...] sean para azer missas y sacrificioss y no para comer ni beber [...]» (ADS, sig. 5567, fol. $11 r)$.

En 1698 se dice en la visita a la cofradía de Nuestra Señora de la Verguería de Lantueno que se encuentran las cuentas «en buena forma [...] aunque en alguna cosa exçesibos los gastos de colaçiones, en que el abbad y mayordomo pondrán la moderaçión que combiene arreglándose a el contenido de la carta pastoral» (ADS, sig. 5538, fol. 24r).

De cómo las advertencias de los inspectores inciden reiterativamente en este punto durante decenios, nos dan buena prueba los testimonios consignados en el libro de la cofradía de San Lorenzo de Pujayo. Así en la visita de 1620, el visitador Francisco de Zorrilla señala, «por quanto la dicha cofradía tiene buenos treinta y siete ducados [y] siete reales y medio, y que los réditos de estos pagan los mayordomos, y los cofrades los gastan en comer y vever sin lo poder ni dever haçer, y ansí se les está mandado por otras visitas empleen dicho dinero y lo destribuyan y gasten en sacrifiçios y obras pías, según en las dichas visitas se contiene [...] las quales se les an notificado a los dichos cofrades y no lo an cumplido" y en 1625 se manda que los réditos: «los gasten en misas y zera para la dicha confradía cumpliendo con el fin prinzipal della» (ADS, sig. 4151, fol. 12r).

${ }_{35}$ ADS, sig. 4151 , fols. 25 r y 22 r (respectivamente). Así, en la visita de 1668 a la cofradía de San Lorenzo de Pujayo se señala que nadie quiere ser mayordomo, con lo cual habrá que señalar a uno obligatorio, que acepte el cargo so pena de excomunión. Y en la de 1692, el visitador señala: «Y en quanto 
cuenta de otras partidas improcedentes en gastos materiales ${ }^{36}$. El reducido muestrario se completa con las alusiones a las disensiones internas y su remedio ${ }^{37}$, más alguna modificación en las reglas ${ }^{38}$. En los siglos XVIII y XIX, el contenido de los informes se vuelve, si cabe, más anodino aún. Circunstancia que creemos no se debe tomar como una prueba de dejación de responsabilidad o desinterés por parte de los visitadores, sino que debe ser interpretada en clave de «normalidad» en el desarrollo de unas actividades que, al menos en la superficie, no plantearon graves problemas (lo que indudablemente influyó en la consecución para las hermandades de elevadas cotas de autogobierno y autonomía).

En consecuencia, nada parece haber, pues, que presente a las cofradías como realidades insumisas o de control dificultoso, como muchas veces se ha tendido a expresar. De hecho, el modelo de las relaciones de poder entre laicos, clero secular, religiosos y jerarquías diocesanas logró expresarse, si no en términos de entente cordiale, sí al menos con un grado de solidez que lo hizo perdurable durante siglos.

al estatuto y costumbre que tienen en hazer colazión el día de la adbocación de dicho santo, dijo su merçed ser contra razón el gastar a quenta de dicha cofradía, y mal permitido, por lo qual mandó que en adelante no se gaste por quenta de el alcançe de dicha cofradía, sino a quenta de dichos cofrades. Y en casso que se haga dicho gasto y asistan a las vísperas y demás devoziones que tienen, dijo su merçed que lo moderaba y moderó a media libra de pan y medio quartillo de vino por cofrade, y no ottra cossa, con aperzivimiento que, si más gastasen, sea a quenta de dichos cofrades, y no del caudal de dicha cofradía, y al mayordomo no se le reçiva otra cossa».

Asimismo, en la visita de 1698 a la cofradía de S. Roque de Monegro se señala: «[...] y por quanto consta de la data de dichas quentas en la colaçión y vevida que los cofrades tienen en cada un año, hacen gastos excessibos y profanos con poco temor de Dios y de sus conçiençias y menoscavo de dicha cofradía, mandó su señoría al Abad, ofiçiales y demás cofrades de ella, en adelante tengan toda moderaçión en dichos gastos, y lo cumplan pena de escomunión mayor y de dos mill maravedís para obras pías [...] en adelante no se exçeda ni passe el gasto de nobenta reales, y si excedieren, lo paguen de sus vienes los mayordomos e yncurran en la çensura y pena de los dichos dos mill maravedís" (ADS, sig. 4355, fol. $6 r$ ).

${ }^{36}$ ADS, sig. 884, fol. 79r. Una variante de advertencia contra estos gastos excesivos en aspectos «materiales» se halla en la visita en la visita efectuada a la cofradía Del Rosario de Proaño (Campóo). En la visita del 9 de diciembre de 1690, el visitador Juan Antonio de Fonceba Castillo, señala, entre otras cosas, que las cuentas están bien sumadas y restadas, aunque con desorden «[...] y muy excessivas en partidas de zera, gastos de tomarlas, derechos de el abbad, y maiordomo, aviéndose tan ympios con una hermandad en que tienen binculados tantos provechos espirituales para sus ánimas, y que deviendo atender a la conservazión y aumento, la defraudan costosos gastos [...]».

37 ADS, sig. 540, fol. 69r. Como sucede en Bárcena de Cudón, donde en la visita de 1690 a la cofradía de la Vera Cruz, se señala lo siguiente: «[...] y asimismo mandó que en caso que entre los hermanos cofrades aya algunas discordias y se querellare[n] ante la justizia ordinaria sin liçenzia del cavildo, se les saque ynremisibleme la condenazión puesta por la regla en este capítulo y se haga cargo de ella al mayordomo. Y esto se encarga al abad y cavildo con espezialidad que lo mandó y firmó».

${ }_{38}$ ADS, sig. 4378, fol. 18r y v. Así, en la visita a la cofradía de Santa María de Hormiguera el licenciado Domingo Marañón señala el día 23 de noviembre de 1701: «[...] Y porque se alla en una de dichas que dichos cofrades deven concurrirles sazerdottes quatro días continuos? a decir misa por el cofrade difunto, y por ser informado su merced, que la mayor parte de dichos cofrades son pobres de solemnidad y por esa razón procuran excusarse de decir en dichos quatro días, quatro misas, las quales dicen no se les pagan y esta razón quieren algunos de ellos y los más dexar la cofradía por petizión presentada están a cumplir una misa de las quatro por el que fuere pobre de solemnidad. Y por que no çese esta obra pía, su merced [...] que para el pobre cofrade se cumpla con una misa con su vigilia y responso [...]". 
El hecho diferencial entre unos tipos de hermandades y otros se extendió también al tamaño de las membrecías. Hay que empezar por decir que algunas instituciones no veían con buenos ojos una expansión incontrolada del número de sus fieles, prohibiendo que éste sobrepasase una cifra prefijada de antemano ${ }^{39}$, pero probablemente fueron una minoría, si nos atenemos a los contenidos de sus escritos fundacionales. Por el contrario, la propia dinámica de propagar una devoción determinada con los beneficios espirituales que ésto comportaba cuadraba muy bien con el espíritu de las nuevas cofradías tridentinas; mientras que, para las más tradicionales, un número crecido de hermanos garantizaba mejor el culto, la asistencia mutua y la brillantez en las procesiones. De esta forma, no es de extrañar que los nuevos ingresos fueran generalmente bienvenidos, aunque, de todas formas, la suerte que corrieron unas cofradías y otras siguió siendo francamente desigual.

Desde luego, y hablando en términos generales, un aspecto que indica de forma relevante hasta qué punto este tipo de asociaciones gozaron del favor de las clases subalternas lo constituye no solamente la rápida expansión geográfica que algunas de ellas experimentaron, sino también el gran número de adhesiones que recibieron en particular. Algunos casos disfrutaron de un enorme éxito inicial, siendo significativa y detallada la lista que nos ofrece la fundación del El Rosario de Bárcena de Cicero el 3 de febrero de 1680 cercana a los 800 miembros, donde se incluyen, además de los miembros, nada menos que 512 «hijos» y 108 «esposas», además de numerosos «nietos» lo que da idea, no solamente de su magnitud, sino de su afán por incluir a toda la colectividad.

Las fuentes consultadas varían en cuanto a la fidelidad y conservación de sus listas de entradas, hecho que dificulta la tarea del historiador, ya que son demasiadas las lagunas y las faltas, en especial en la dimensión temporal. Por ejemplo, en lo que respecta a la consignación de las listas de hermanos, éstas suelen ser «fundacionales», es decir, que los miembros se consignan por entero solamente una vez, cuando se funda la hermandad. Después se proporcionan únicamente los datos de ingresos, pero no las muertes ni los abandonos, con lo cual, al cabo de unos años, es difícil saber cual es la entidad numérica real de la asociación. También parece frecuente el hecho de que, en ciertas cofradías, a partir del siglo XVIII no se anoten en los libros los ingresos, centrándose estos únicamente en los aspectos económicos, por lo que es preciso deducir éstos de las cantidades monetarias consignadas en el "Cargo» de las cuentas anuales por dicho concepto, una práctica arriesgada (a la que no nos ha quedado más remedio que acudir en ocasiones) y que, en el mejor de los casos, no permite determinar ni siquiera el género de los nuevos cofrades.

No obstante, con respecto a lo que las fuentes nos permite evaluar, no cabe duda de que la realidad numérica media fue modesta, por lo que se puede afirmar que la cofradía tipo post-tridentina de la región cántabra tuvo escala humana.

${ }^{39}$ ADS, sig. 6844, fol. 6r y v. Es el caso, por ejemplo de Nuestra Señora del Humano, en Campóo de Yuso, que prefija dicho número en 150 miembros. 
Esta aseveración es algo que se puede comprobar con facilidad estudiando casos especialmente bien documentados, como el de Santa Marina de Valdeprado, que presenta registros cuasi-completos ${ }^{40}$ desde 1682 a 1841. En la mencionada cofradía se puede constatar un total de 180 ingresos documentados en una perfecta solución de continuidad, un número limitado, aunque no irrelevante. Para el análisis de este caso particular se han recogido todos los asientos determinando el estado de los ingresantes (hombres, mujeres casadas, viudas, solteras, mujeres sin especificar, hombres solteros, sacerdotes y casos sin especificar) que presentamos cuantificados en el CUADRO 4, divididos en dos bloques, tanto los que aparecen en el acta fundacional, como los ingresos documentados desde el año 1709, a partir del cual aparecen ya establemente y de forma continua hasta 1841.

Cuadro 4. Los ingresos en la Cofradía de Santa Marina de Valdeprado, por períodos: 1682-1841

\begin{tabular}{|c|c|c|c|c|c|c|c|c|c|}
\hline Período & $\mathbf{C 1}$ & $\mathbf{C 2}$ & $\mathbf{C 3}$ & $\mathbf{C 4}$ & $\mathbf{C 6}$ & $\mathbf{C 7}$ & $\mathbf{C 8}$ & $\mathbf{C 9}$ & Totales \\
\hline 1682 & 23 & 6 & 1 & 0 & 6 & 0 & 17 & 0 & 53 \\
\hline $1709-25$ & 1 & 0 & 5 & 0 & 1 & 0 & 5 & 0 & 12 \\
\hline $1726-50$ & 6 & 8 & 4 & 0 & 1 & 0 & 6 & 0 & 25 \\
\hline $1750-75$ & 16 & 8 & 1 & 0 & 8 & 0 & 5 & 1 & 39 \\
\hline $1776-00$ & 16 & 16 & 1 & 3 & 1 & 1 & 5 & 0 & 29 \\
\hline $1801-25$ & 1 & 4 & 0 & 0 & 2 & 2 & 4 & 1 & 14 \\
\hline $1825-42$ & 1 & 1 & 1 & 0 & 1 & 2 & 1 & 1 & 8 \\
\hline Total & $\mathbf{6 4}$ & $\mathbf{2 9}$ & $\mathbf{1 3}$ & $\mathbf{3}$ & $\mathbf{2 0}$ & $\mathbf{3 2}$ & $\mathbf{4 3}$ & $\mathbf{3}$ & $\mathbf{1 8 0}$ \\
\hline
\end{tabular}

Fuente: Elaboración propia a partir de ADS, Valdeprado, Cofradía de Sta. Marina, sig. 1486.

Ciertamente, la media con que nos encontramos en el período continuo que va desde 1709 a 1842 sobrepasa en muy poco el ingreso de una persona por año, teniendo en cuenta que en algunas de las décadas fue aún menor. Por tanto, nos encontramos ante un tipo de hermandad sodalicia de características reducidas, que va cubriendo los huecos de las personas difuntas con nuevas incorporaciones en un equilibrio difícil, pero que posee la vitalidad suficiente como para sobrevivir durante siglos. Dichas incorporaciones son irregulares y, aunque estemos tratando con cifras reducidas, podemos contemplar cómo existieron períodos de sequía muy prolongados, en tanto que en otros aumentó de forma considerable el número de nuevos cofrades ${ }^{41}$.

40 Probablemente existe una pérdida de los mismos o un no asentamiento, por causas desconocidas, entre 1682 y 1709.

41 En lo referente a los «estados» de los mismos, el número de ingresos es excesivamente corto como para pretender establecer conclusiones, aunque, no obstante, observamos que los dos grupos es 
No obstante, no parece que en los siglos anteriores las cosas fueran sustancialmente distintas, ya que estas asociaciones muestran un empuje considerable al inicio de su andadura, para ir estabilizándose en los años posteriores, aunque sin perder nunca lo que podríamos denominar el mínimo de capacidad regenerativa. Tenemos distintos ejemplos que prueban ésto, como las cifras de ingresos (de una calidad y antigüedad infrecuentes) que encontramos en la hermandad de Nuestra Señora de El Moral de Valdeiguña a lo largo de tres siglos ${ }^{42}$ y dicha «vitalidad plurisecular» podemos encontrarla en otros lugares, lo que ya constituye una observación importante en sí, como es el caso de la Vera Cruz de Caranceja ${ }^{43}$. De cara a clarificar el ejemplo, se han ido anotando todas las partidas de ingresos desde el año en que comienzan sus registros (1616) hasta el año 1777, en que dejan de citarse $^{44}$. En términos generales sus cifras supondrían un mantenimiento (que se trocaría incluso en un aumento considerable en la penúltima veintena del siglo XVIII, es decir la última que conservamos completa), sin problemas en cuanto al número de los cofrades, lo que resulta un ejemplo más (claro y contundente) de que la mayoría de estas instituciones no sufrieron mermas de consideración en lo referente

pecificados más importantes (hombres y mujeres casadas) consiguen su máximo en el último cuarto del siglo XVIII. Por su parte, los sacerdotes experimentaron un corto pero decidido declive casi desde el principio, así como las viudas que se incorporaron a la hermandad. No deja de ser curioso que todos los grupos sociales analizados terminen prácticamente igual, lo que demuestra perfectamente un declive general de la cofradía en el período tardío comprendido entre 1825 y 1842.

42 ADS, sig. 488. Dicha hermandad agrupó alrededor de un esquema devocional, típicamente supralocal y aglutinante, diferentes valles y lugares ganaderos de la cuenca del Alto Besaya y se reestructuró en el siglo XVI (con toda probabilidad, la devoción original es muy anterior). En su evolución se aprecia una continuidad aceptable en los ingresos hasta bien entrado el Setecientos, con cotas que alcanzan, incluso, cifras mayores que las de la centuria anterior. Desgraciadamente, no se constatan incorporaciones detalladas con posterioridad a 1727, aunque la cofradía continuase y en el mismo libro aparece en 1818 una fundación (posiblemente una reconversión de la misma) de El Rosario que cuenta nada menos que con 322 miembros (de los cuales 151 son hombres, 170 mujeres y 1 caso sin especificar), lo que viene a indicar, si no una supervivencia de la devoción concreta (lo menos relevante en este caso, pues se trata además de dos advocaciones marianas), sí un claro exponente de la vitalidad socio-religiosa de la propia institución.

${ }^{43}$ ADS, sig. 6950. Los datos serían los siguientes (año, hombres, mujeres y observaciones): 1616: 5 h. 9 m. (4 hombres de disciplina 2 mujeres de «luz».);1687: 5 h. 11 m.; 1689: 3 h. 1 m. (1 hombre de disciplina);1690: 7 h. 6 m.( 2 hombres de disciplina);1690: 1 h., 0 m. (de disciplina):1699: 7 h., 11 m. (4 hombres de disciplina);1700: 0 h., 4 m. (3 mujeres de luz);1703: 1 h.,1 m. (forman matrimonio);1704: 2 h., 1 m. (1 hombre de disciplina);1705: 1 h. 0 m.;1706: 4 h. ,4 m. (2 hombres de disciplina);1708: 6 h., 5 m. (4 hombres de disciplina, un hombre de luz);1709, 3 h., 4 m. (1 hombre de disciplina y otro de luz);1710: 2 h., 2 m. (2 hombres de disciplina);1712: 3 h., 1 m. ;1713: 0 h. 2 m. ;1714: 1 h., 1 m. (1 hombre de disciplina);1715: 1 h., 8 m. (1 hombre de disciplina);1716: 2 h., 0 m. (1 hombre de luz);1718: 1 h., 0 m.;1719: 2 h., 0 m. (los 2 de disciplina); 1720: 5 h,. 4 m., (2 hombres de disciplina, 1 mujer de luz); 1721: 3 h., 5 m. (1 hombre de disciplina);1723: 4 h., 2 m.;1724: 1 h., 1 m.;1725: 3 h., 1 m. ; 1726:3 h.,1 m. ;1728: 1 h. 1 m. ;1729: 4 h., 4 m.;1730: 1 h., 1 m.; 1731: 1 h., 0 m.; 1732; 0 h., 1 m.; 1733: 2 h.. 7 m. (2 hombres de disciplina); 1744: 1 h., 4 m.;1745: 4 h., 3 m.; 1747: 0 h., 2 m.; 1753: 6 h., 8 m.;1762: 1 h., 1 m.;1763: 3 h. ,1 m.; 1764: 1 h., 3 m. ;1772: 1 h., 6 m.; 1775: 7 hermanos/as, sin esp.; 1776: 0 h., 2 m.; 1777: 1 h., 0 m. ; 1778: 4 hermanos/as, sin esp.; 1779: 11 hermanos/as sin esp.; 1780: 3 hermanos/as sin esp.; 1781: 5 hermanos/as sin esp.; 1782, 10 hermanos/as sin esp 1784: 1 hermanos/as sin esp.; 1785: 4 hermanos/as sin esp.; 1787: 2 hermanos/as sin esp.; 1807: 6 hermanos/as sin esp.; 1808: 2 hermanos/as sin esp.; 1811: 6 hermanos/as sin esp.

44 Aunque se ha seguido el ritmo de las entradas, bien que sin especificar su identidad ni su sexo, como es natural, deduciendo las misma de los aportes económicos consignados por este concepto en el «cargo» de las cuentas anuales hasta 1811. 
a su capacidad regenerativa natural durante los tres siglos que abarca nuestro estudio. La formula de piedad asociativa plasmada por el modelo de cofradía post-tridentina, se revela así como una entidad numéricamente importante y cronológicamente duradera, dos parámetros que dan la medida plena de su éxito.

Otro aspecto de interés sería el estudio de la evolución de los distintos grados de compromiso dentro de ella, como podría ser, por ejemplo, la determinación en las hermandades de disciplinantes de la variabilidad del número de «cofrades de sangre» con respecto del total. En este punto nuestra investigación confirma, en líneas generales, las escasas investigaciones que hasta la fecha se han realizado al respecto, en el sentido de un lento abandono de la práctica a partir de las primeras décadas del siglo XVII, tras una indudable etapa de esplendor en los decenios centrales de la centuria anterior. Incluso en la propia documentación parece abandonarse paulatinamente el interés por cualquier tipo de diferenciación entre unos cofrades y otros, tanto en sus distintos roles dentro de la hermandad, como incluso en su género.

Como conclusión, podríamos afirmar que las cofradías jugaron un papel de cierta importancia en la configuración de los arquetipos de la práctica y manifestaciones de la religiosidad del período, aunque sea absolutamente imprescindible resaltar la diferencia entre el modelo generalista y el particularizante, y sus diferentes correspondencias en el ámbito de las creencias piadosas y sus manifestaciones respectivas. Su vida fue longeva, con numerables altibajos y derivas devocionales. Gozaron de un éxito general muy estimable en cuanto a su extensión, aunque de carácter desigual. No nos sentimos inclinados a suponer que sus logros tuvieran consecuencias extraordinarias en el ámbito extra-religioso, debido a la estereotipificación de unas prácticas altamente reguladas, posiblemente interiorizadas desde estándares de routine, y con alto grado de contaminaciones de tipo representativo-social. La escasa documentación que generaron, en cualesquiera otros aspectos, parece reforzar nuestra afirmación. En todo caso, la misma razón nos hace rechazar doblemente la teoría que presenta este tipo de asociaciones sodalicias como reductos de una cultura popular, expresada en torno a rituales comensalísticos y de expresión solidaria, que vendiese cara su asimilación así como el magnificente instrumento del proceso confesionalizador que terminaría por transformar sustancialmente las costumbres de las clases subalternas. Ciertamente no puede desdeñarse el papel de las hermandades sodalicias, pero hay otros elementos, de carácter más privado, que en nuestra opinión tuvieron una relevancia mucho mayor en la construcción del imaginario religioso popular. 